\title{
Confronting the vicinity of the surface water and sea shore in a shallow glaciogenic aquifer in southern Finland
}

\author{
S. Luoma ${ }^{1}$, J. Okkonen ${ }^{2}$, K. Korkka-Niemi ${ }^{3}$, N. Hendriksson ${ }^{1}$, and B. Backman ${ }^{1}$ \\ ${ }^{1}$ Geological Survey of Finland, P.O. Box 96, 02151 Espoo, Finland \\ ${ }^{2}$ Geological Survey of Finland, P.O. Box 97, 67101 Kokkola, Finland \\ ${ }^{3}$ Department of Geosciences and Geography, University of Helsinki, P.O. Box 64, 00014 Helsinki, Finland \\ Correspondence to: S. Luoma (samrit.luoma@gtk.fi)
}

Received: 24 June 2014 - Published in Hydrol. Earth Syst. Sci. Discuss.: 25 July 2014

Revised: 3 February 2015 - Accepted: 24 February 2015 - Published: 12 March 2015

\begin{abstract}
The groundwater in a shallow, unconfined, lowlying coastal aquifer in Santala, southern Finland, was chemically characterised by integrating multivariate statistical approaches, principal component analysis (PCA) and hierarchical cluster analysis (HCA), based on the stable isotopes $\delta^{2} \mathrm{H}$ and $\delta^{18} \mathrm{O}$, hydrogeochemistry and field monitoring data. PCA and HCA yielded similar results and classified groundwater samples into six distinct groups that revealed the factors controlling temporal and spatial variations in the groundwater geochemistry, such as the geology, anthropogenic sources from human activities, climate and surface water. High temporal variation in groundwater chemistry directly corresponded to precipitation. With an increase in precipitation, $\mathrm{KMnO}_{4}$ consumption, EC, alkalinity and Ca concentrations also increased in most wells, while $\mathrm{Fe}, \mathrm{Al}, \mathrm{Mn}$ and $\mathrm{SO}_{4}$ were occasionally increased during spring after the snowmelt under specific geological conditions. The continued increase in $\mathrm{NO}_{3}$ and metal concentrations in groundwater indicates the potential contamination risk to the aquifer. Stable isotopes of $\delta^{18} \mathrm{O}$ and $\delta^{2} \mathrm{H}$ indicate groundwater recharge directly from meteoric water, with an insignificant contribution from lake water, and no seawater intrusion into the aquifer. Groundwater geochemistry suggests that local seawater intrusion is temporarily able to take place in the sulfate reduction zone along the freshwater and seawater mixed zone in the low-lying coastal area, but the contribution of seawater was found to be very low. The influence of lake water could be observed from higher levels of $\mathrm{KMnO}_{4}$ consumption in wells near the lake. The integration of PCA and HCA with conventional classification of groundwater types, as well as with the hydrogeochemical data, provided useful tools to
\end{abstract}

identify the vulnerable groundwater areas representing the impacts of both natural and human activities on water quality and the understanding of complex groundwater flow system for the aquifer vulnerability assessment and groundwater management in the future.

\section{Introduction}

Shallow permeable aquifers located next to the sea shore may face greater risks and challenges in water consumption and management compared with inland water intakes. Aquifers along the coastline are especially vulnerable to seawater intrusion, either due to sea level rise or storm surges (e.g. Oude Essink, 1999, 2001; Barlow, 2003; Pulido-Leboeuf, 2004; Oude Essink et al., 2010; Rasmussen et al., 2013; Luoma et al., 2013; Luoma and Okkonen, 2014), which will presumably be accelerated by the changing climate (IPCC, 2000, 2007; Nicholls et al., 2007). Besides these, increasing water demand for the population and industries as well as changing land use practises as a result of human activities, e.g. exceeding the water intake, gravel excavation pits, car parking, and groundwater contamination risk areas, can expose shallow aquifers to contamination. Ferguson and Gleeson (2012) reported that, due to the groundwater abstraction and low hydraulic gradient, the saltwater intrusion into the coastal aquifer will be more widespread and significant than assumed by the impact of sea level rise.

Under the changing climate, a potential increase in precipitation in winter, spring and autumn and increased evapotranspiration in summer owing to rising temperatures is expected 
(Scibek and Allen, 2006; Scibek et al., 2007; Jyrkama and Sykes, 2007; Okkonen and Kløve, 2011; Okkonen, 2011; Luoma and Okkonen, 2014). Climate change would potentially affect not only the groundwater, but also the surface water. For sustainable groundwater resource management and land use planning, it is important to understand the hydrogeological processes and the interactions between groundwater and surface water, and factors affecting groundwater quality.

Approximately 300 out of the total of 6000 classified shallow groundwater areas in Finland (excluding Åland) are located $100 \mathrm{~m}$ or less from the shore of the Baltic Sea (Hertta database, SYKE, 2013). The Baltic Sea is one of the largest brackish water areas in the world (EEA, 1999). Although the low salinity, which varies from 3.0 to $7.0 \%$ in the Gulf of Finland (Alenius et al., 1998; UNEP, 2005; Fagerlund, 2008), does not pose a high risk from seawater intrusion compared to other parts of the world (e.g. Oude Essink, 1999, 2001; Barlow, 2003; Pulido-Leboeuf, 2004; Oude Essink et al., 2010; Rasmussen et al., 2013), the salinity is at a higher level than the drinking water standard, and in the long term it can damage the infrastructure such as the pipeline network.

Seasonal variations in groundwater quality have been reported in many unconfined shallow aquifers in Finland. For example, a lower dissolved concentration of elements in groundwater during the snowmelt period indicates effects of the snowmelt (Backman et al., 1999; Korkka-Niemi, 2001; Okkonen, 2012). However, there is still no clear understanding of the interactions between surface water and groundwater or the impacts of brackish water intrusion on shallow, low-lying coastal aquifers. Major ion chemistry, as well as the stable isotopic composition of oxygen-18 $\left(\delta^{18} \mathrm{O}\right)$ and hydrogen $\left(\delta^{2} \mathrm{H}\right.$ or deuterium), could be used to assess these interactions, as reported earlier by Allen (2004), Harbison (2007), Kortelainen (2007) and Mongelli et al. (2013), among others.

A shallow glaciogenic aquifer in the Hanko area in southern Finland, our case study area, is confronting these issues in an attempt to maintain water quality within the drinking water standards in the long term. As reported by Luoma and Okkonen (2014), a rise in the sea level due to the global climate change would cause some parts of the Hanko aquifer to be under the sea level, compromising groundwater quality due to seawater intrusion. This, together with the predicted increase in precipitation, would increase groundwater recharge and raise the groundwater levels, consequently contributing to the potential deterioration of groundwater quality or potential flooding in the low-lying aquifer.

The objective of this study was to address the following questions. (1) What are the factors controlling groundwater quality, the main water type and the chemical evolution of groundwater in the low-lying coastline aquifer in cold, snow-dominated southern Finland? (2) Is there any influence of seawater on groundwater quality? (3) What are the interactions between the Baltic Sea and lake and groundwater, and the temporal and spatial variations in groundwater and surface water geochemistry in different recharge periods? (4) How can the hydrogeochemical data be used in order to indicate vulnerable areas of the coastal aquifer?

The data comprised field investigation and hydrogeochemical data obtained during 2010 and 2012. The stable isotope ratios of $\delta^{18} \mathrm{O}$ and $\delta^{2} \mathrm{H}$ were used to determine the origin of groundwater. The geochemistry of water samples was analysed and classified with multivariate statistical methods, i.e. hierarchical cluster analysis (HCA) and principal component analysis (PCA) (Cloutier et al., 2008), in conjunction with conventional groundwater classification using Piper diagrams.

\section{The study area}

The study area is located in Santala on the northern coast of the Hanko peninsula, southern Finland, at approx. $59^{\circ} 53^{\prime \prime} \mathrm{N}$, $23^{\circ} 10^{\prime \prime} \mathrm{E}$ (Fig. 1), and covers approx. $17 \mathrm{~km}^{2}$ of the main aquifer. This aquifer is an important source of drinking water and the water supply for Hanko (with a population of 9282 in 2013) and local industries. The aquifer consists of porous gravels and sands of an ice-marginal end deposit, and is located in a low-lying coastal area bounded by the Baltic Sea, with a lake in the middle of the aquifer. The topographic landform varies between 10 and $14 \mathrm{~m}$ a.s.l. along the northern ridge of the First Salpausselkä Quaternary ice-marginal formation (Fig. 1) and its elevation decreases to less than $2 \mathrm{~m}$ along the northern coastline, while in the south and southeast the elevation gradually decreases to 5-7 $\mathrm{m}$ a.s.l. The southern part is partly covered by wetlands and peatlands. In the east, the area is covered by sand dune terrain from the Aeolian deposit. The lake and wetlands in the middle of the aquifer are located in a depression that forms part of the First Salpausselkä formation and the sand dune terrain. The lake has a surface area of about $1.8 \mathrm{~km}^{2}$, and it is shallow, with an average depth of approximately $1-2 \mathrm{~m}$. In many parts of the aquifer, the groundwater level is close to the ground surface, and water intake areas are located along the coastline, where the groundwater level may often fall below the sea level. The groundwater level has previously been observed to rapidly respond to a rise in the sea level, as well to recharge from the spring snowmelt and rainfall (Backman et al., 2007; Luoma et al., 2013). Additionally, human activities in the area, such as gravel excavation pits, local industries or the highway (Fig. 1), could pose a contamination risk to the groundwater quality.

The Hanko area belongs to the temperate coniferousmixed forest climate zone with cold, wet winters. During the study period, the mean annual temperature remained at approximately $+6^{\circ} \mathrm{C}$, which is consistent with the long-term mean annual temperature in the reference period of 19812010 (FMI, 2013). Meteorological parameters (maximum, minimum and mean temperatures, precipitation and snow) both in 2012 and during the period of 1981-2010 measured 


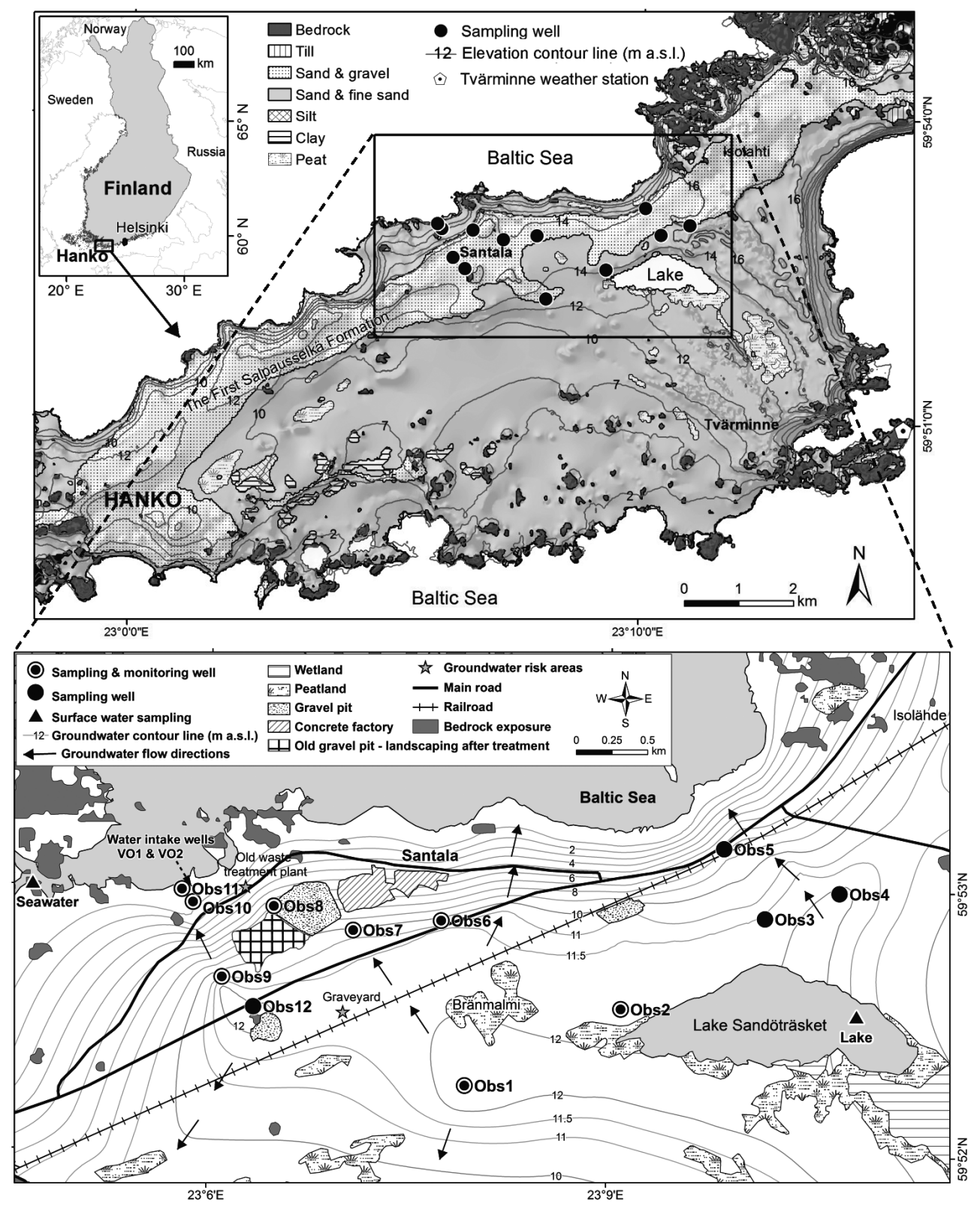

Figure 1. Location and Quaternary geological deposit map of the study area in the eastern Baltic Sea region.

at the Tvärminne weather station, approx. 5 to $8 \mathrm{~km}$ southeast of the study area, are illustrated in Fig. 2. The lowest daily temperatures are generally recorded in January and February, and the highest during July and August (Fig. 2). The year 2012 was exceptionally rainy, as the cumulative amount of annual precipitation was $893 \mathrm{~mm}$. This is $41 \%$ higher than the long-term mean value of $634 \mathrm{~mm}$ (1981-2010).

The stratigraphy in the Hanko area is underlain by the basement of the Precambrian crystalline igneous and metamorphic rock and is covered by the Quaternary deposits. The Precambrian bedrock, which mainly consists of granite, quartz diorite and granodiorites, forms a sharp contact with the Quaternary deposits, with some outcrops in the area (Kielosto et al., 1996). The aquifer in the study area is situated in the First Salpausselkä ice-marginal formation deposited during the Weichselian and Holocence deglaciation of the Scandinavian Ice Sheet (Fyfe, 1991; Saarnisto and Saarinen, 2001). The First Salpausselkä ice-marginal formation consists of glacial till, gravel, sand and clay, together with postglacial littoral gravel, sand and clay (Fig. 1).

The primary ice-marginal formation in Hanko was formed in deep water with a low narrow ridge (Fyfe, 1991). When the ice sheet withdrew from the area, this formation was covered by fine-grained sediments, silt and clay layers of the Ancy- 


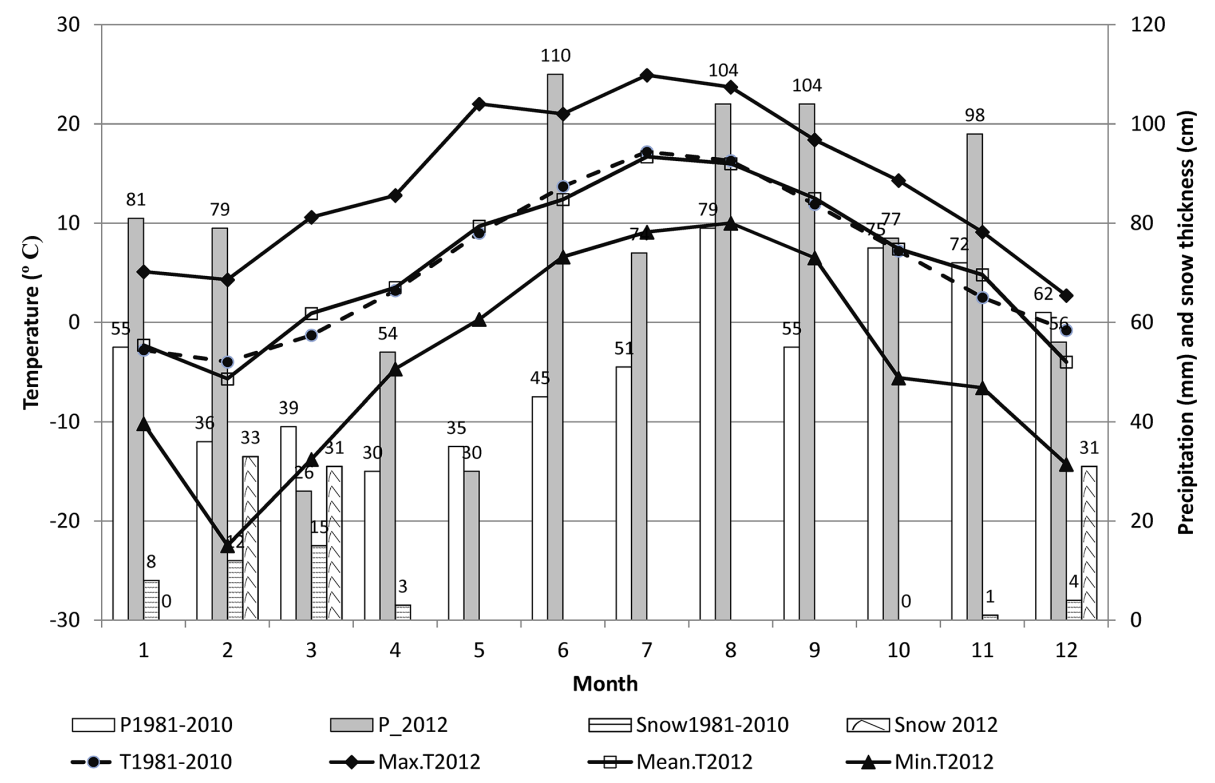

Figure 2. Monthly maximum, mean, and minimum temperatures (solid lines, in ${ }^{\circ} \mathrm{C}$ ), monthly precipitation (grey bar, in mm, as rainfall and snow) and snow thickness (wavy bar, in $\mathrm{cm}$ ) at the Tvärminne weather station in Hanko during January-December 2012. Mean monthly temperature (dash line, in ${ }^{\circ} \mathrm{C}$ ), monthly precipitations (white bar, in mm, as rainfall and snow) and snow thickness (straight line bar, in $\mathrm{cm}$ ) of years 1981-2010 are plotted for comparison. Data are received from FMI (2013).

lus Lake and Littorina Sea. The sea level has been regressive since the glacial period due to isostatic land uplift. The primary deposit of the First Salpausselkä formation was exposed to sea waves and also to wind (Kielosto et al., 1996). The well-sorted gravels indicate the reworking of materials resulting from the high energy of wave and storm activities over a large area in Santala, the study area, while fine sand from Aeolian deposits covers a large area to the east and southeast of the lake (Fig. 1) (Fyfe, 1991; Kielosto et al., 1996).

The shallow aquifer in Hanko is unconfined, with the thickness of the Quaternary deposits varying from less than $1 \mathrm{~m}$ to $75 \mathrm{~m}$, and the average thickness being about $25 \mathrm{~m}$. The sediments are generally thick on the western side, in a NE-SW direction conforming to the First Salpausselkä formation, and decrease eastward to less than $1 \mathrm{~m}$ in the eastern coast area. The groundwater table in Santala is between 2 and $7 \mathrm{~m}$ below the ground surface in the inland area, and less than $2 \mathrm{~m}$ below the ground surface in the coastal area, where groundwater discharges into the Baltic Sea. The results of well testing and soil sample analysis have revealed that the hydraulic conductivity of the aquifer varies from 0.3 to $4.8 \mathrm{~m} \mathrm{~d}^{-1}$ in silty sand and fine sand, and up to $100 \mathrm{~m} \mathrm{~d}^{-1}$ in sand and gravel (Luoma and Pullinen, 2011). Groundwater recharge mainly occurs twice a year during spring (late March to early April) and late autumn (November to early December) from the infiltration of snowmelt and rainfall (Luoma et al., 2013). Groundwater mainly flows northwards into the coastal area and also towards the south-southeast into the wetlands and peatlands, as well as towards the Baltic Sea in the east.

\section{Materials and methods}

\subsection{Sampling, field investigation and well monitoring}

The field investigation and water sampling were carried out four times, during the winter, spring, summer and autumn of 2012. Water samples were collected from 15 sites in the Santala area, including water samples from 12 groundwater observation wells (Table 1), the lake, the Baltic Sea, and a water intake well (Fig. 1). In total, 26 samples were taken for chemical analysis and 59 samples for the analysis of stable isotope compositions of oxygen and hydrogen. In addition, water chemical analysis results for six water samples taken during spring 2010, as well as groundwater monitoring data (depth $(D)$, temperature $(T)$, electrical conductivity (EC) and field measurement data, including $D, T, \mathrm{EC}, \mathrm{pH}$, dissolved oxygen $\left(\mathrm{O}_{2}\right)$, redox potential (Eh) and dissolved carbon dioxide $\left.\left(\mathrm{CO}_{2}\right)\right)$ for 12 wells in the Hanko area performed during 2009-2010, were used to support the interpretation.

The field investigation consisted of the down-hole profile logging and field measurement of water samples during water sampling. The profile logging was performed in order to investigate the vertical distribution of physical and chemical parameters of groundwater at the screen intervals of the observation wells, and the water sampling depths were selected based on the results of these logs. The measurement was per- 
Table 1. Observation well information of the sampling depth, screen depth, and vadose zone thickness during the sampling periods. The negative vadose zone thickness means that the well was flooded during the measurement.

\begin{tabular}{|c|c|c|c|c|c|c|c|c|c|}
\hline \multirow[t]{2}{*}{ Well } & \multirow{2}{*}{$\begin{array}{r}\text { Sampling } \\
\text { depth from } \\
\text { ground } \\
\text { surface } \\
(\mathrm{m})\end{array}$} & \multirow{2}{*}{$\begin{array}{r}\text { Depth of } \\
\text { diver from } \\
\text { ground } \\
\text { surface } \\
\text { (m) }\end{array}$} & \multirow{2}{*}{$\begin{array}{r}\text { Screen } \\
\text { interval } \\
\text { from } \\
\text { ground } \\
\text { surface }(\mathrm{m})\end{array}$} & \multirow{2}{*}{$\begin{array}{r}\text { Screen } \\
\text { length } \\
\text { (m) }\end{array}$} & \multirow{2}{*}{$\begin{array}{r}\text { Well } \\
\text { depth } \\
(\mathrm{m})\end{array}$} & \multirow{2}{*}{$\begin{array}{r}\text { Vadose } \\
\text { zone } \\
\text { thickness } \\
\text { in winter } \\
(\mathrm{m})\end{array}$} & \multicolumn{3}{|c|}{$\begin{array}{l}\text { Sediments between ground } \\
\text { surface and screen bottom }(\%)\end{array}$} \\
\hline & & & & & & & $\begin{array}{r}\text { Silt \& fine } \\
\text { sand }\end{array}$ & Sand & Gravel \\
\hline Obs1 & 8 & 7 & $5.8-17.8$ & 12 & 17.8 & 1.80 & 35 & 48 & 17 \\
\hline Obs2 & 10 & 8 & $3.5-18.5$ & 15 & 28.5 & 1.62 & 63 & 38 & \\
\hline Obs3 & 10 & No diver & $5.4-32.4$ & 27 & 36.4 & 3.89 & 14 & & 86 \\
\hline Obs4 & 10 & No diver & $7.2-25.2$ & 18 & 36.2 & 4.95 & 16 & 25 & 59 \\
\hline Obs5 & 8 & No diver & $4.8-10.8$ & 6 & 10.8 & 5.90 & & & 100 \\
\hline Obs6 & 9 & 8 & $4.0-49.0$ & 45 & 49.0 & 1.39 & 56 & 11 & 33 \\
\hline Obs6 & 7 & \multicolumn{2}{|c|}{ Partition sample - top } & & & & & & \\
\hline Obs6 & 12 & \multicolumn{2}{|c|}{ Partition sample - bottom } & & & & & & \\
\hline Obs7 & 7 & 8 & $5.7-8.7$ & 3 & 8.7 & 2.95 & 88 & 4 & 8 \\
\hline Obs8 & 9 & 13 & $6.9-31.9$ & 25 & 31.9 & 6.58 & 20 & 22 & 58 \\
\hline Obs8 & 7.7 & \multicolumn{2}{|c|}{ Partition sample - top } & & & & & & \\
\hline Obs8 & 13.7 & \multicolumn{2}{|c|}{ Partition sample - bottom } & & & & & & \\
\hline Obs9 & 10 & 8 & $6.0-14$ & 8 & 17.0 & 2.79 & & 45 & 55 \\
\hline Obs10 & 6 & 4 & $1.4-8.4$ & 7 & 8.4 & 1.61 & 11 & 64 & 24 \\
\hline Obs11 & 6 & 5 & $1.7-8.7$ & 7 & 8.7 & -0.15 & 39 & 32 & 29 \\
\hline Obs 12 & 4 & No diver & $1.0-5.0$ & 4 & 5.0 & 1.88 & 31 & 38 & 31 \\
\hline
\end{tabular}

formed by using either a WTW P4 instrument (during the winter) or a YSI Professional Plus (IP-67), a multi-parameter recording device, for the measurement of $\mathrm{EC}, \mathrm{pH}, T, \mathrm{O}_{2}$ and Eh. Dissolved carbon dioxide $\left(\mathrm{CO}_{2}\right)$ was measured in the field by using a colorimetric titration method (Csuros, 1994) with $0.02 \mathrm{~N} \mathrm{NaOH}$, while alkalinity was measured by using automatic potentiometric titration immediately upon arrival of the samples at the laboratory. The pumping rate, time, and amount of water pumped before sampling were recorded. In addition, the groundwater tables were measured before and after pumping.

Well monitoring was carried out for eight groundwater observation wells from March to November 2012 and in Lake Sandösträsket from September to November 2012. Measurement was performed by installing a Schlumberger MiniDiver data logger and pressure transducer at the same sampling depths. Three wells located near the northern coastline area were monitored for $T, D$ and EC. Lake water and five inland wells, which were situated far from the coastline and the water intake well, were monitored for $T$ and $D$. All data were recorded hourly. Time series of climate data (air temperature and precipitation as rainfall or snow thickness) and sea level recordings in the Hanko area from the same period were obtained from the Finish Meteorological Institute (FMI, 2013) and used for comparison.

The groundwater from the observation wells was pumped for a minimum of $20 \mathrm{~min}$ until all parameter readings (e.g. $T$, EC) were constant before sampling. Groundwater from the water intake well was taken from the tap by allowing wa- ter to flow out until all parameters (e.g. $T$, EC) were constant. The surface water samples (seawater and lake water) were taken with a Limnos water sampler from $1 \mathrm{~m}$ below the water surface. The number and sampling depth of groundwater samples from each well were selected according to the profile-logged results. If there were no variations in the profile, a sample was taken from the middle of the screen inter$\mathrm{val}$, at least $2 \mathrm{~m}$ below the top screen. If there were variations in the profile, the partition samples were taken by placing an inflatable packer at the discrete depth of the selected zones, and a single groundwater sample was collected at a time, beginning with the top section and continuing downwards to the bottom section.

\subsection{Analytical methods and quality control}

For cation analysis, water samples were filtered through $0.45 \mu \mathrm{m}$ membrane filters and collected into $100 \mathrm{~mL}$ highdensity polyethylene (HDPE) bottles. The samples were acidified and analysed in the accredited laboratory of Labtium Ltd in Espoo. Filtered and acidified water samples were analysed for major and minor elements $(\mathrm{Ag}, \mathrm{Al}, \mathrm{As}, \mathrm{B}$, $\mathrm{Ba}, \mathrm{Be}, \mathrm{Bi}, \mathrm{Cd}, \mathrm{Co}, \mathrm{Cr}, \mathrm{Cu}, \mathrm{I}, \mathrm{K}, \mathrm{Li}, \mathrm{Mn}, \mathrm{Mo}, \mathrm{Ni}, \mathrm{P}, \mathrm{Pb}, \mathrm{Rb}$, $\mathrm{Sb}, \mathrm{Se}, \mathrm{Sr}, \mathrm{Th}, \mathrm{Tl}, \mathrm{U}, \mathrm{V}, \mathrm{Ca}, \mathrm{Fe}, \mathrm{Mg}, \mathrm{Na}, \mathrm{Si}$ and $\mathrm{S}$ ) by using inductively coupled plasma atomic emission and mass spectrometry (ICP-AES and ICP-MS). Alkalinity $\left(\right.$ as $\left.\mathrm{HCO}_{3}\right)$, EC, $\mathrm{pH}$ and $\mathrm{KMnO}_{4}$ consumption were measured from unfiltered and unpreserved samples immediately upon arrival of the samples at the laboratory. They were also analysed for an- 
ions $\left(\mathrm{Br}, \mathrm{Cl}, \mathrm{F}, \mathrm{NO}_{3}, \mathrm{PO}_{4}\right.$ and $\left.\mathrm{SO}_{4}\right)$ using ion chromatography (IC). To ensure the quality of the equipment and chemical analysis, a zero sample was prepared from distilled water and four duplicate pairs of groundwater samples were also analysed. The zero and duplicated sample analysis results indicated no field contamination. The charge balance error (BE) (Drever, 1997) was calculated for all water samples. For 26 of the 34 water samples, $\mathrm{BE}< \pm 5 \%$, while 8 samples had BE values between \pm 6 and $\pm 10 \%$. The chemical analysis and quality control results from Labtium Ltd indicated high proportions of anions in some water samples, and the BE cutoff of $\pm 10 \%$ was acceptable. Many previous studies, such as Appelo and Postma (2005) and Allen (2004), have recommended a BE cutoff of less than $\pm 5 \%$ for good water analysis, while Drever (1997) and Harbison (2007) used a BE cutoff of $\pm 10 \%$ due to the presence of high organic acid concentrations in fresh groundwater samples from a shallow coastal aquifer.

\subsection{Stable isotope oxygen and hydrogen analysis}

The stable isotopes $\delta^{18} \mathrm{O}$ and $\delta^{2} \mathrm{H}$ are commonly used in studies on groundwater flow and the interaction of groundwater and surface water. These traditional water isotopes are effective tracers that can be used to identify the origin of water as well as the mixing processes of isotopically distinct water masses and evaporation in surface water reservoirs (Gonfiantini, 1986; Richter and Kreitler, 1993; Taylor and Howard 1996; Clark and Fritz, 1997; Kendall and McDonnell, 1998; Allen, 2004; Faure and Mensing, 2005). The recent regional isotopic composition of both atmospheric precipitation and groundwater are well known in southern Finland (Kortelainen, 2007; Kortelainen and Karhu, 2004). Based on monthly isotopic values of oxygen and hydrogen in Finnish precipitation, the national-scale meteoric water line $\left(\delta^{2} \mathrm{H}=7.67 \delta^{18} \mathrm{O}+5.79 \%\right.$ ) was established by Kortelainen in 2007. The line agrees well with local lines derived for the southern coast of Finland (Kortelainen, 2007, 2009) and could consequently be applied in this study. In temperate climates such as in Finland, the isotopic composition of the local groundwater closely follows that of local precipitation (Kortelainen, 2007; Kortelainen and Karhu, 2004). The stable isotope method has been widely applied in Finland, especially to evaluate natural groundwater-surface water interaction (Rautio and Korkka-Niemi, 2011) and artificially enhanced surface water infiltration into aquifers (Kortelainen and Karhu, 2006; Hendriksson et al., 2012).

For analysis of the stable isotopes $\delta^{18} \mathrm{O}$ and $\delta^{2} \mathrm{H}$, filtered water samples $(<45 \mu \mathrm{m})$ of about $60 \mathrm{~mL}$ were collected in HDPE bottles and were kept in a dark cooler box and out of direct sunlight during transport to the Research Laboratory of Geological Survey of Finland in Espoo. The isotopic composition of $\delta^{18} \mathrm{O}$ and $\delta^{2} \mathrm{H}$ was analysed by laserbased cavity ring-down spectroscopy (CRDS), using a Picarro isotopic water analyser. In the CRDS method, the ab- solute abundances of water molecules with different combinations of the stable isotopes of $\delta^{18} \mathrm{O}$ and $\delta^{2} \mathrm{H}$ are measured from a vaporised sample in an optic chamber. The isotopic composition of water is reported using the $\delta$ notation per mill (\%o) relative to the VSMOW (Vienna Standard Mean Ocean Water) standard. The $\delta$ value is defined as $\delta=$ $\left(\left(R_{\mathrm{SA}}-R_{\mathrm{VSMOW}}\right) / R_{\mathrm{VSMOW}}\right) \times 1000$, where $\mathrm{SA}$ is the sample and VSMOW is the standard, $\delta=\delta^{18} \mathrm{O}$ and $R={ }^{18} \mathrm{O} /{ }^{16} \mathrm{O}$ for oxygen, and $\delta=\delta^{2} \mathrm{H}$ and $R={ }^{2} \mathrm{H} / \mathrm{H}$ for hydrogen. The repeatability of analyses was $<0.1 \%$ ofor $\delta^{18} \mathrm{O}$ and $<0.5 \%$ o for $\delta^{2} \mathrm{H}$.

\subsection{Statistical analysis}

Data correlations and statistical analyses were performed using the IBM SPSS statistical package (IBM SPSS Statistics, 2013) to determine the variables that represent the controlling factors behind the geochemistry of all the water samples taken during April and August 2012. The correlations between variables were carried out for all raw data by using the Pearson correlation coefficient to identify the relationships between variables among the water sampling sites.

Two multivariate statistical approaches, principal component analysis (PCA) and hierarchical cluster analysis (HCA), were used to group the water samples or variables analysed. PCA is a factor analysis method that is used to extract components representing the information contained in the data that explain the pattern of correlations and differences within a group of variables (Korkka-Niemi, 2001; IBM SPSS Statistics, 2013). The number of factors or components was extracted by PCA with Varimax rotation based on Kaiser normalisation.

HCA is a classification method that reveals natural groupings or clusters within a data set by reorganizing the data into homogeneous groups and linking the two most similar clusters until all of the variables are joined in a complete classification tree (Korkka-Niemi, 2001; IBM SPSS Statistics, 2013). The results of HCA are presented in a dendrogram, which is constructed using Ward's method (Ward, 1963) with the Euclidean distance as a measure of similarity between the samples. Ward's method is one of the most widespread hierarchical clustering methods for the classification of hydrogeochemical data by using the minimum variance to evaluate the distances between the clusters (Güler et al., 2002; Cloutier et al., 2008; Templ et al., 2008).

The data used for PCA and HCA comprised the stable isotopes $\delta^{2} \mathrm{H}$ and $\delta^{18} \mathrm{O}$, chemical parameters, $\mathrm{pH}$ and EC. The data set includes variables having normal or close to normal distributions from the chemical parameters (alkalinity, B, Ba, $\mathrm{Ca}, \mathrm{I}, \mathrm{Li}, \mathrm{Mg}, \mathrm{Na}, \mathrm{Rb}, \mathrm{S}, \mathrm{Si}$ and $\mathrm{Sr}$ ), and $\delta^{2} \mathrm{H}, \delta^{18} \mathrm{O}, \mathrm{pH}$ and EC. The variables having a non-normal distribution $(\mathrm{Al}, \mathrm{Cl}$, $\mathrm{Cu}, \mathrm{Mn}, \mathrm{K}, \mathrm{KMnO}_{4}, \mathrm{Mo}, \mathrm{Ni}, \mathrm{NO}_{3}, \mathrm{SO}_{4}, \mathrm{U}$ and $\mathrm{Zn}$ ) were logtransformed prior to statistical analysis. The variables below or close to the detection limit $(\mathrm{Ag}, \mathrm{Be}, \mathrm{Bi}, \mathrm{Br}, \mathrm{Cd}, \mathrm{Co}, \mathrm{Cr}$, $\mathrm{F}, \mathrm{Fe}, \mathrm{P} \mathrm{PO}_{4}$, Se, Th and $\mathrm{Tl}$ ) were excluded from the anal- 
ysis. The data were standardised by subtracting the sample mean from each variable and dividing the resulting value by the standard deviation ( $\mathrm{Z}$ score standardisation) prior to multivariate analysis to ensure that each variable was weighted equally (Güler et al., 2002; Cloutier et al., 2008; Templ et al., 2008).

\subsection{Data processing}

Data analysis was performed in Microsoft Excel for data storage, cross-plots and basic calculation. GWChart (USGS, 2012) was used to produce piper diagrams, which are plots of the relative concentration of major dissolved species of anions and cations, in order to identify the water types (Piper, 1944; Appelo and Postma, 2005). ArcGIS/ArcMap was used for visualisation of the geochemical data points and the groundwater level was mapped by kriging. For comparison with the chemical analysis results from the water samples, median values of groundwater compositions of Finnish shallow aquifers (Lahermo et al., 2002) and the precipitation (rainfall and snowmelt) collected from the Tvärminne weather station (Vuorenmaa et al., 1999; Järvinen and Vänni, 1996, 1997), as well as recommended values for drinking water for Finnish household wells from the Ministry of Social Affairs and Health (STM, 2001) were used as references.

\section{Results}

\subsection{Water levels}

The results of lake level monitoring during September to November 2012, groundwater levels from monitoring wells during March to November 2012 and daily precipitation and temperature data from the Tvärminne weather station in the Hanko area (FMI, 2013) are presented in Fig. 3. The variation in groundwater levels indicated that the main recharge takes place twice a year: during spring (early April) immediately after the snowmelt period (Fig. 3b), when groundwater reaches its highest level, and during late autumn (October to December). Groundwater levels reached the lowest levels during the winter and late summer due to the snow cover and evapotranspiration, respectively. The mean groundwater levels ranged from $8.4 \mathrm{~m}$ a.s.1. at Obs8 to $12.3 \mathrm{~m}$ a.s.1. at Obs1 for the inland wells, and from $0.4 \mathrm{~m}$ a.s.l. at Obs 11 to $0.5 \mathrm{~m}$ a.s.l. at Obs10 for the wells in the coastal area. The time series of lake level data during September to November 2012 varied from 11.83 to $11.98 \mathrm{~m}$ a.s.l. (Fig. 3b). The previous measurements of lake levels during this study were $11.75 \mathrm{~m}$ a.s.l. in November 2009 and $12.08 \mathrm{~m}$ a.s.l. in January 2012. The variation in lake levels during the year was less than $0.5 \mathrm{~m}$. Sampling point Obs 2 is located approximately $170 \mathrm{~m}$ west of the lake shoreline. The groundwater level at Obs2 during March to November 2012 varied between 11.13 and $11.79 \mathrm{~m}$ a.s.l., which is lower than the lake level. The fluctuation in the groundwater level at Obs2 was positively corre-

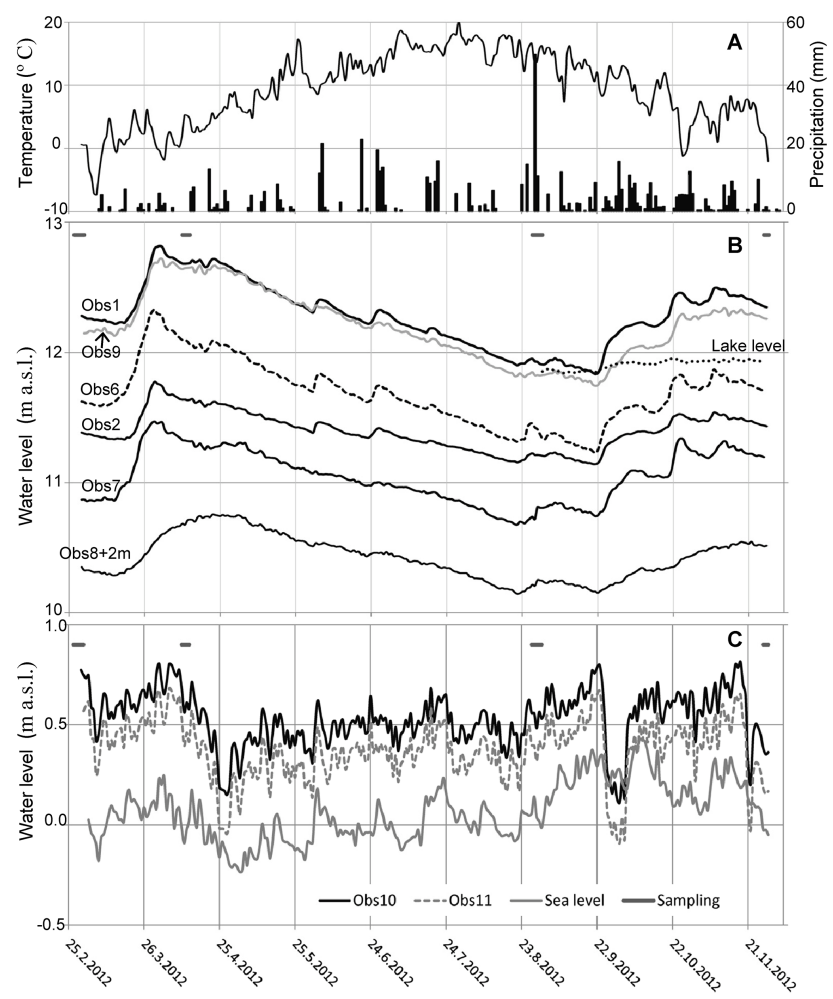

Figure 3. (a): daily temperature (line) and precipitation (bar) during March-November 2012 from the Tvärminne weather station, Hanko (FMI, 2013). (b): groundwater levels from monitoring wells during the same periods for wells locate in the mainland and lake level during September-November 2012. (c): groundwater levels from wells locate nearby the coastline and sea level data. The groundwater level of Obs8 was shifted up $2 \mathrm{~m}$ in order to get all the data fitted into one figure. The sample periods are present on the top of (b) and (c).

lated with the lake level, with a Pearson correlation coefficient of $0.94(\rho<0.01)$.

\subsection{Geochemistry of water}

Summary statistics for the groundwater and surface water geochemistry are presented in Table 2 . The EC profile logging at Obs8 and Obs6 revealed higher values in the top section than in the bottom section of the observation well. The partition samples were taken from Obs8 and Obs6 during the summer for chemical and stable isotopic analysis, and during autumn for stable isotopic analysis. Figure 4 presents the profile $\log$ results from Obs6 and the sampling depths. The bottom samples could not be taken from a deeper depth because the packer became stuck in the observation well at certain depths.

\subsection{Stable isotopes of oxygen and hydrogen}

The $\delta^{2} \mathrm{H}$ and $\delta^{18} \mathrm{O}$ values of groundwater varied spatially and temporally within the range of -86.90 to $-76.50 \%$ VS- 


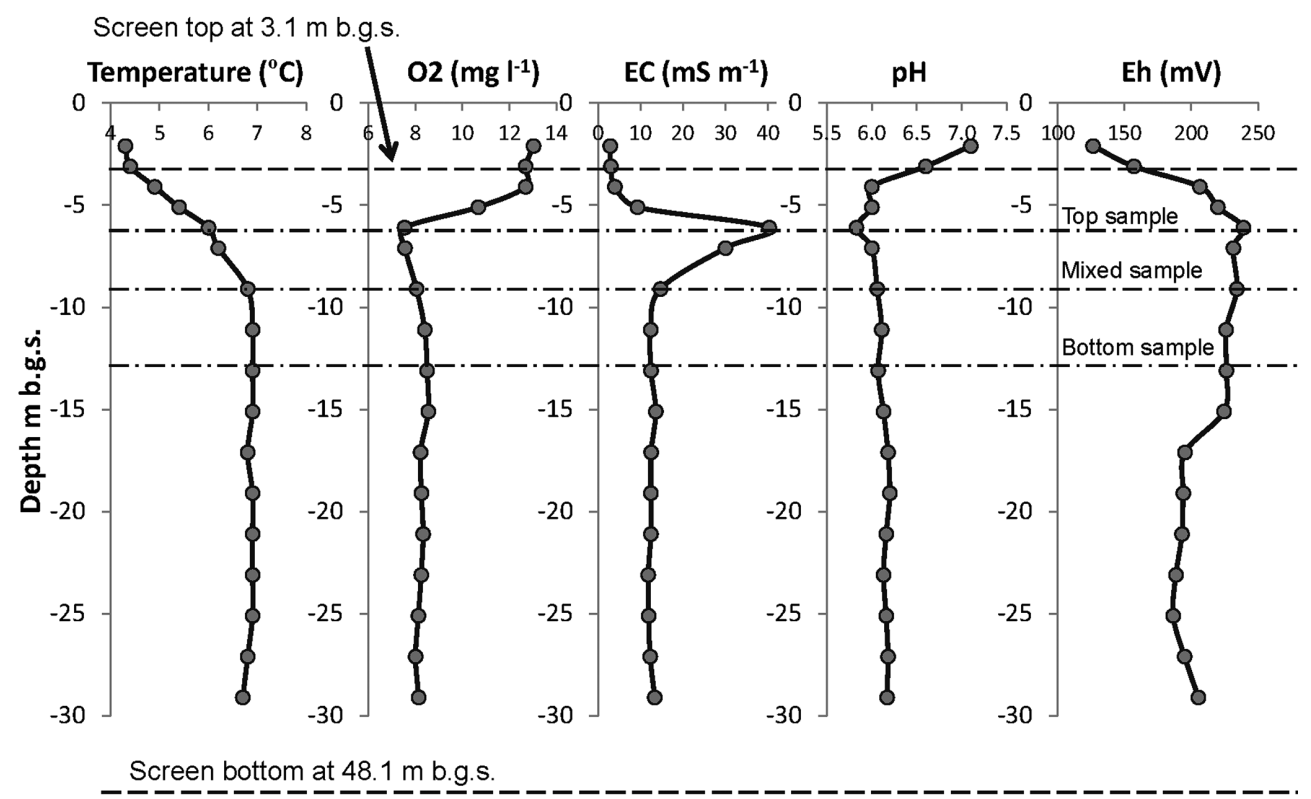

Figure 4. Depth profile of parameters: temperature, dissolved oxygen $\left(\mathrm{O}_{2}\right)$, electrical conductivity $(\mathrm{EC})$, pH and redox potential $(\mathrm{Eh})$, in the well screen section of Obs6 (50 $\mathrm{m}$ from the highway) during spring 2012. $\mathrm{m}$ b.g.s $=$ metres below ground surface.

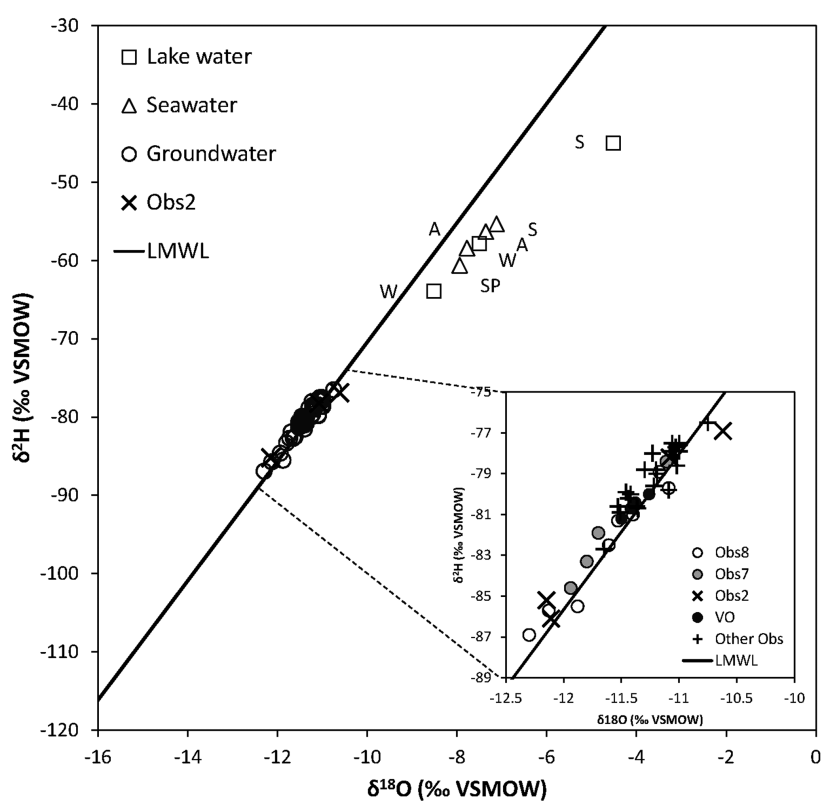

Figure 5. Plot of the $\delta^{2} \mathrm{H}$ and $\delta^{18} \mathrm{O}$ data for lake water, seawater, groundwater from the observation wells (Obs), and the water intake well (VO) from Santala during 2012 with the Finnish local meteoric water line (LMWL) for comparison. Labels at surface water indicate the sampling period: $\mathrm{S}=$ summer, $\mathrm{SP}=$ spring, $\mathrm{A}=$ autumn and $\mathrm{W}=$ winter. Locations of water samplings are showed in Fig. 1.

MOW and -12.30 to $-10.62 \%$ VSMOW, with mean values of $-80.39 \pm 2.52(1 \sigma) \%$ and $-11.37 \pm 0.36(1 \sigma) \%$ o VSMOW, respectively. The mean $\delta^{2} \mathrm{H}$ and $\delta^{18} \mathrm{O}$ values for the lake water were $-55.57 \pm 9.65$ and $-6.85 \pm 2.08 \%$, re- spectively, and the respective values for the seawater were $-57.65 \pm 2.35$ and $-7.55 \pm 0.38 \%$. The variations of the $\delta^{2} \mathrm{H}$ and $\delta^{18} \mathrm{O}$ data from 59 water samples collected in Santala are presented in Fig. 5 .

\section{Discussions}

\subsection{Origin of groundwater}

The stable isotopes $\delta^{2} \mathrm{H}$ and $\delta^{18} \mathrm{O}$ were used to differentiate the meteoric origin of groundwater from a surface water origin. The $\delta^{2} \mathrm{H}$ and $\delta^{18} \mathrm{O}$ values in groundwater from this study were consistent with the results of Kortelainen and Karhu (2004) and Kortelainen (2007), who reported mean $\delta^{2} \mathrm{H}$ and $\delta^{18} \mathrm{O}$ values of groundwater from southern Finland $(n=37)$ of $-82.0 \pm 0.9$ and $-11.55 \pm 0.14 \%$ VSMOW, respectively. The stable isotopes $\delta^{2} \mathrm{H}$ and $\delta^{18} \mathrm{O}$ of groundwater in Santala are also consistent with the mean $\delta^{2} \mathrm{H}$ and $\delta^{18} \mathrm{O}$ values of the precipitation from southern Finland $(n=60)$, which are $-82.0 \pm 23.6$ and $-11.54 \pm 3.1 \%$ o VSMOW, respectively. These values are distinct from those of surface water, as the mean $\delta^{2} \mathrm{H}$ and $\delta^{18} \mathrm{O}$ values of lake water are $-55.57 \pm 9.6$ and $-6.85 \pm 2.1 \%$, respectively, and the respective means of seawater are $-57.65 \pm 2.4$ and $-7.55 \pm 0.4 \%$.

Most of the $\delta^{2} \mathrm{H}$ and $\delta^{18} \mathrm{O}$ values of groundwater from Santala fall closely on the Finnish local meteoric water line (Fig. 5, LMWL), indicating direct recharge from precipitation (snowmelt and rainfall) with no indication of evaporation or a contribution from the surface water. Due to evaporation, the $\delta^{2} \mathrm{H}$ and $\delta^{18} \mathrm{O}$ values of lake and seawater deviate to 
Table 2. Characteristics of groundwater in the Santala area, Hanko (number of samples $n=32$ ) compared with data from lake water, seawater, the median values from Lahermo et al. (2002) and precipitation from Vuorenmaa et al. (1999) and Järvinen and Vänni (1997, 1996), and safe drinking water (STM, 2001).

\begin{tabular}{|c|c|c|c|c|c|c|c|c|c|c|}
\hline Variable & Unit & Min. & Median & Mean & Max. & $\begin{array}{r}\text { Lake } \\
\text { water } \\
(n=1)\end{array}$ & $\begin{array}{l}\text { Seawater } \\
\quad(n=1)\end{array}$ & $\begin{array}{r}\text { Lahermo } \\
\text { et al. }(2002) \\
(n=739)\end{array}$ & $\begin{array}{l}\text { Precip. } \\
(n=36)\end{array}$ & $\begin{array}{r}\text { Drinking } \\
\text { water }\end{array}$ \\
\hline Temperature & ${ }^{\circ} \mathrm{C}$ & 5.70 & 7.00 & 7.39 & 10.40 & 8.50 & 7.80 & 6.80 & & \\
\hline $\mathrm{Eh}$ & $\mathrm{mV}$ & 161 & 255 & 258 & 354 & 279 & 230 & & & \\
\hline $\mathrm{O}_{2}$ & $\mathrm{mg} \mathrm{L}^{-1}$ & 0.84 & 5.19 & 6.08 & 11.7 & 7.70 & 13.1 & 60.9 & & \\
\hline $\mathrm{CO}_{2}$ & $\mathrm{mg} \mathrm{L}^{-1}$ & 1.00 & 12.0 & 12.1 & 36.0 & 6.33 & 1.00 & 34.0 & & \\
\hline $\mathrm{EC}$ & $\mathrm{mS} \mathrm{m}^{-1}$ & 3.75 & 13.4 & 13.6 & 30.2 & 4.51 & 826 & & 2.82 & 250 \\
\hline $\mathrm{pH}$ & & 5.50 & 6.55 & 6.61 & 8.00 & 6.20 & 8.41 & & 4.50 & $6.5-9.5$ \\
\hline $\mathrm{Na}$ & $\mathrm{mg} \mathrm{L}^{-1}$ & 1.76 & 3.10 & 5.11 & 14.7 & 3.04 & 1360 & 4.18 & 0.66 & \\
\hline $\mathrm{K}$ & $\mathrm{mg} \mathrm{L}^{-1}$ & 0.31 & 0.86 & 1.39 & 4.84 & 0.24 & 59.2 & 2.78 & 0.16 & \\
\hline $\mathrm{Ca}$ & $\mathrm{mg} \mathrm{L}^{-1}$ & 2.48 & 9.94 & 17.0 & 47.0 & 3.38 & 69.3 & 11.4 & 0.40 & \\
\hline $\mathrm{Mg}$ & $\mathrm{mg} \mathrm{L}^{-1}$ & 0.64 & 1.54 & 1.85 & 4.63 & 1.01 & 162 & 2.38 & 0.12 & \\
\hline $\mathrm{Cl}$ & $\mathrm{mg} \mathrm{L}^{-1}$ & 1.50 & 3.50 & 6.50 & 28.3 & 3.60 & 2690 & 4.46 & 1.10 & 100 \\
\hline $\mathrm{SO}_{4}$ & $\mathrm{mg} \mathrm{L}^{-1}$ & 5.30 & 9.50 & 13.2 & 38.3 & 7.40 & 356 & 10.4 & 0.90 & 250 \\
\hline $\mathrm{NO}_{3}$ & $\mathrm{mg} \mathrm{L}^{-1}$ & $<0.2$ & 0.75 & 1.97 & 7.00 & 1.50 & $<20$ & 3.19 & 0.53 & 50.0 \\
\hline Alkalinity & $\mathrm{mmol} \mathrm{L}^{-1}$ & 0.10 & 0.45 & 0.85 & 2.43 & 0.07 & 1.42 & 0.54 & & \\
\hline $\mathrm{HCO}_{3}$ & $\mathrm{mg} \mathrm{L}^{-1}$ & 6.10 & 27.5 & 52.1 & 148 & 4.27 & 86.6 & 32.9 & & \\
\hline $\mathrm{KMnO}_{4}$ & $\mathrm{mg} \mathrm{L}^{-1}$ & 0.32 & 1.80 & 2.56 & 10.0 & 21.0 & 26.0 & 4.50 & & 20.0 \\
\hline $\mathrm{Al}$ & $\mu \mathrm{g} \mathrm{L}^{-1}$ & 1.02 & 9.89 & 37.7 & 227 & 12.0 & 9.98 & 101 & & 200 \\
\hline $\mathrm{Mn}$ & $\mu \mathrm{g} \mathrm{L}^{-1}$ & 0.06 & 2.14 & 15.1 & 80.8 & 3.18 & 7.07 & 4.36 & & 100 \\
\hline $\mathrm{Fe}$ & $\mathrm{mg} \mathrm{L}^{-1}$ & $<0.03$ & 0.08 & 0.15 & 0.31 & 0.06 & $<0.03$ & $<0.03$ & & 0.40 \\
\hline As & $\mu g \mathrm{~L}^{-1}$ & $<0.05$ & 0.26 & 0.39 & 1.12 & 0.37 & 0.65 & 0.14 & & 10.0 \\
\hline B & $\mu g \mathrm{~L}^{-1}$ & 4.46 & 10.4 & 10.8 & 24.3 & 8.40 & 579 & 13.8 & & 1000 \\
\hline $\mathrm{Cd}$ & $\mu \mathrm{g} \mathrm{L}^{-1}$ & $<0.02$ & 0.03 & 0.04 & 0.12 & 0.03 & $<0.02$ & $<0.02$ & & 5.00 \\
\hline $\mathrm{Cr}$ & $\mu g \mathrm{~L}^{-1}$ & $<0.20$ & 0.39 & 0.47 & 1.15 & $<0.20$ & $<0.20$ & 0.20 & & 50 \\
\hline $\mathrm{Cu}$ & $\mu g \mathrm{~L}^{-1}$ & $<0.10$ & 0.66 & 1.23 & 4.39 & 0.37 & 0.85 & 2.49 & & 2000 \\
\hline $\mathrm{Ni}$ & $\mu \mathrm{gL}^{-1}$ & $<0.05$ & 1.28 & 2.19 & 10.6 & $<0.05$ & 0.95 & 0.84 & & 20.0 \\
\hline $\mathrm{Pb}$ & $\mu \mathrm{g} \mathrm{L}^{-1}$ & $<0.05$ & 0.09 & 0.10 & 0.17 & 0.38 & 0.06 & 0.04 & & 10.0 \\
\hline $\mathrm{Sb}$ & $\mu \mathrm{g} \mathrm{L}^{-1}$ & 0.02 & 0.04 & 0.04 & 0.13 & 0.11 & 0.11 & 0.03 & & 5.00 \\
\hline $\mathrm{Se}$ & $\mu \mathrm{g} \mathrm{L}^{-1}$ & $<0.50$ & 1.57 & 1.61 & 1.87 & $<0.50$ & 25.1 & $<0.5$ & & 10.0 \\
\hline $\mathrm{F}$ & $\mathrm{mg} \mathrm{L}^{-1}$ & $<0.10$ & 0.24 & 0.31 & 0.73 & $<0.10$ & $<1.00$ & $<0.1$ & & 1.40 \\
\hline $\mathrm{Ba}$ & $\mu \mathrm{g} \mathrm{L}^{-1}$ & 0.85 & 3.51 & 5.04 & 16.7 & 2.80 & 19.6 & 18.1 & & \\
\hline $\mathrm{Br}$ & $\mathrm{mg} \mathrm{L}^{-1}$ & $<0.10$ & $<0.10$ & $<0.10$ & $<0.10$ & $<0.10$ & 19.1 & 9.92 & & \\
\hline I & $\mu g \mathrm{~L}^{-1}$ & $<2.00$ & 4.68 & 6.44 & 19.8 & 2.62 & & 2.12 & & \\
\hline $\mathrm{Li}$ & $\mu \mathrm{g} \mathrm{L}^{-1}$ & $<0.10$ & 1.47 & 1.98 & 6.94 & 1.41 & 25.3 & 0.77 & & \\
\hline $\mathrm{PO}_{4}$ & $\mathrm{mg} \mathrm{L}^{-1}$ & $<0.02$ & 0.03 & 0.04 & 0.13 & $<0.02$ & 0.10 & $<0.02$ & & \\
\hline $\mathrm{Si}$ & $\mathrm{mg} \mathrm{L}^{-1}$ & 3.64 & 6.13 & 6.57 & 9.85 & 0.10 & 0.37 & & & \\
\hline $\mathrm{Sr}$ & $\mu g \mathrm{~L}^{-1}$ & 13.0 & 42.7 & 62.6 & 163 & 11.9 & 1300 & 59.9 & & \\
\hline $\mathrm{Zn}$ & $\mu \mathrm{gL}^{-1}$ & 0.69 & 4.20 & 7.20 & 53.4 & 12.2 & 7.75 & 10.4 & & \\
\hline
\end{tabular}

the right from the LMWL. The higher the evaporation effect is, the further to the right the values deviate from the local groundwater and the LMWL (Gonfiantini, 1986). In surface waters, high seasonal variations are also recorded (Fig. 5). The variations are larger in lake water than in seawater. Both lake and sea water show the highest evaporation effect in the summer samples.

The only sign of possible mixing of groundwater and surface water was observed from a sample taken in spring
(11 April 2013) at Obs2, approx. $170 \mathrm{~m}$ west of the lake shoreline, where slightly higher $\delta^{2} \mathrm{H}$ and $\delta^{18} \mathrm{O}$ values were recorded than in the autumn, and a small deviation from the LMWL. Water monitoring data implied that the water flow direction was from the lake into Obs2. The $\mathrm{KMnO}_{4}$ consumption of samples from Obs2 in April 2012 and August 2012 were high relative to the surrounding wells, and close to the concentration from lake water, which indicates the influence of lake water on this well. 


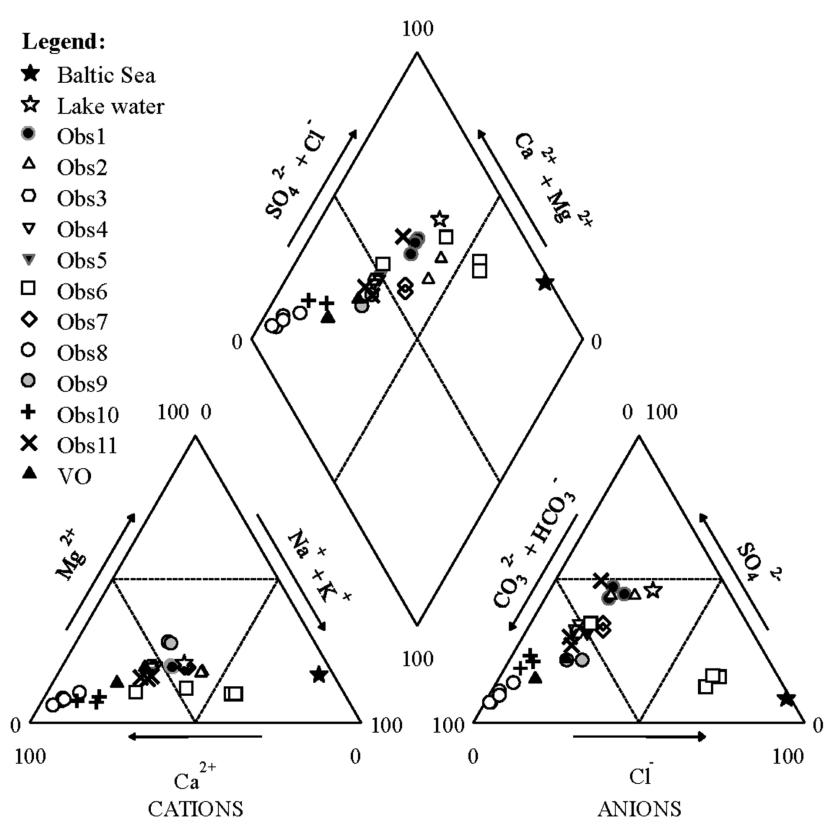

Figure 6. Piper diagram showing the major ion chemistry of groundwater and surface water samples from Santala, Hanko.

The majority of the groundwater samples, including the top and bottom samples from Obs6 (except from Obs8, Obs7 and Obs2), showed narrow temporal and spatial variation with low standard deviations of 1.6 and $0.23 \%$ for $\delta^{2} \mathrm{H}$ and $\delta^{18} \mathrm{O}$, respectively (Fig. 5). At Obs6, where the multilevel samples were taken, small variations were observed in $\delta^{2} \mathrm{H}$ and $\delta^{18} \mathrm{O}$ between the top and bottom samples; furthermore, the samples at each interval (top or bottom) displayed very small seasonal variations between summer and autumn. The narrow variations of most of the data may indicate the same source of groundwater recharge with a short percolation time. The fluctuation in groundwater levels in many observation wells (Fig. 3) indicates a rapid response of the groundwater level to precipitation during the snowmelt period and heavy rainfall events, which reflect the short percolation time. This is consistent with many wells that contain quite a thin vadose zone (Table 1) and/or the high hydraulic conductivity of aquifer materials. However, the observation wells next to a gravel excavation pit (Obs8, Obs7) and the lake shoreline (Obs2) showed high seasonal variation with high standard deviations of 3.21 and $0.49 \%$ for the $\delta^{2} \mathrm{H}$ and $\delta^{18} \mathrm{O}$, respectively. High temporal and spatial variation in $\delta^{2} \mathrm{H}$ and $\delta^{18} \mathrm{O}$ was more clearly observed in the top and bottom samples from Obs8. This high variation may indicate a short percolation time and the influence of surface water from the gravel excavation pit and lake water.

The median concentrations of major ions in the groundwater were low and close to the median concentrations of precipitation (Vuorenmaa et al., 1999; Järvinen and Vänni, 1996, 1997), being lower than the median values of shallow groundwater in Finland (Lahermo et al., 2002). The concentrations of minor ions and trace elements $(\mathrm{F}, \mathrm{Fe}, \mathrm{Ag}, \mathrm{Be}, \mathrm{Bi}$, $\mathrm{Br}, \mathrm{Cd}, \mathrm{Co}, \mathrm{Cr}, \mathrm{P}, \mathrm{PO}_{4}, \mathrm{Se}, \mathrm{Th}$ and $\mathrm{Tl}$ ) in many wells were below or close to the detection limit. However, the median values of metals and trace elements such as $\mathrm{Fe}, \mathrm{As}, \mathrm{Cd}, \mathrm{Cr}$, $\mathrm{Ni}, \mathrm{Pb}, \mathrm{Sb}, \mathrm{Se}, \mathrm{I}, \mathrm{Li}$ and $\mathrm{PO}_{4}$ from groundwater samples were higher than those reported by Lahermo et al. (2002) (Table 2).

The piper diagram in Fig. 6 illustrates that the composition of groundwater in Santala is mainly of the $\mathrm{Ca}-\mathrm{HCO}_{3}$ type, with no cation exchange taking place, and only the top and mixed samples from Obs6 fall closer to the $\mathrm{Na}-\mathrm{Cl}$ type. The $\mathrm{Ca}-\mathrm{HCO}_{3}$ type of groundwater, with low dissolved ion concentrations, low $\mathrm{pH}$, alkalinity, $\mathrm{Ca}$ and $\mathrm{Mg}$, is a common groundwater type for glaciated areas in Finland (e.g. Backman et al., 1999; Soveri et al., 2001; Korkka-Niemi, 2001; Lahermo et al., 2002; Backman, 2004). Allen (2004) reported that this type of groundwater indicates young groundwater derived from direct percolation or having a short resident time, or that no substrate, e.g. clay minerals, is present for cation exchange. This is consistent with the finding of low dissolved concentrations of elements in many groundwater samples.

The chloride concentrations of all groundwater samples varied between 1.5 and $28.3 \mathrm{mg} \mathrm{L}^{-1}$, and differed considerably from the seawater sample, which had a $\mathrm{Cl}$ concentration of $2690 \mathrm{mg} \mathrm{L}^{-1}$. Elevated $\mathrm{Na}$ and $\mathrm{Cl}$ concentrations found in top sample from Obs6 were much higher than those in the bottom sample from the same observation well in and nearby wells, and they had no correlations with the other variables. Obs6 is situated about $50 \mathrm{~m}$ in a downstream direction from the highway running through the middle of the aquifer. Elevated concentrations of $\mathrm{Na}$ and $\mathrm{Cl}$ in this well indicate the influence of de-icing chemicals $(\mathrm{NaCl})$ in the top section of Obs6, while the bottom section contained low dissolved concentrations overall, which were the same as in the nearby wells. The use of salt for de-icing purposes in Finland increased in 1987, with a peak in 1990, when $157000 \mathrm{t}$ of salt was applied along the highways in southern Finland. Many of these run on top of the First Salpausselkä formation, including the Hanko area. There have been attempts to reduce the use of de-icing road salt since 1993 (Gustafsson and Nystén, 2000). The aquifer materials in the area of Obs6 consist of the interbedded layers of sand and fine-grained sediments (Luoma et al., 2013). The fine-grained layers could prevent the distribution of $\mathrm{Na}$ and $\mathrm{Cl}$ from groundwater to the top section of the well.

No intrusion of seawater was observed in Obs10 or Obs11, which are located close the coastline and the water intake well. The chloride concentration of seawater in this study was $2690 \mathrm{mg} \mathrm{L}^{-1}$, which is consistent with other studies, e.g. Alenius et al. (1998) and Fagerlund (2008). The Cl contribution to the groundwater in Obs10 and Obs11, calculated from the $\mathrm{Cl}$ concentrations of water samples, seawater and fresh water (Appelo and Postma, 2005), was less than 0.5\%, 
Table 3. Principal component loadings from factor analysis and explained variances of geochemical variables and stable isotopes $\delta^{2} \mathrm{H}$ and $\delta^{18} \mathrm{O}$ of water samples. Factor loadings $>0.7$ are marked as bold.

\begin{tabular}{|c|c|c|c|c|}
\hline \multirow[t]{2}{*}{ Parameter } & \multicolumn{4}{|c|}{ Principal component (PC) } \\
\hline & 1 & 2 & 3 & 4 \\
\hline$\delta^{2} \mathrm{H}$ & -0.08 & -0.17 & 0.86 & -0.05 \\
\hline$\delta^{18} \mathrm{O}$ & -0.13 & -0.14 & 0.86 & -0.05 \\
\hline $\mathrm{KMnO}_{4}\left(\mathrm{mg} \mathrm{L}^{-1}\right)$ & 0.19 & 0.12 & 0.82 & 0.03 \\
\hline $\mathrm{SO}_{4}\left(\mathrm{mg} \mathrm{L}^{-1}\right)$ & 0.86 & 0.27 & 0.11 & 0.23 \\
\hline $\mathrm{K}\left(\mathrm{mg} \mathrm{L}^{-1}\right)$ & 0.83 & 0.40 & -0.11 & 0.20 \\
\hline $\operatorname{Mo}\left(\mu \mathrm{g} \mathrm{L}^{-1}\right)$ & 0.78 & 0.47 & -0.15 & -0.13 \\
\hline $\operatorname{Mg}\left(\mathrm{mg} \mathrm{L}^{-1}\right)$ & 0.75 & 0.24 & -0.07 & 0.28 \\
\hline $\mathrm{I}\left(\mu \mathrm{g} \mathrm{L}^{-1}\right)$ & 0.75 & 0.25 & 0.00 & 0.20 \\
\hline $\mathrm{Ba}(\mu \mathrm{g} \mathrm{L}-1)$ & 0.82 & 0.17 & 0.23 & 0.26 \\
\hline $\operatorname{Mn}\left(\mu \mathrm{gL}^{-1}\right)$ & 0.75 & -0.27 & 0.40 & 0.26 \\
\hline $\mathrm{Cu}\left(\mu \mathrm{gL}^{-1}\right)$ & 0.81 & 0.34 & 0.37 & -0.10 \\
\hline $\mathrm{Si}\left(\mathrm{mg} \mathrm{L}^{-1}\right)$ & 0.69 & -0.40 & -0.43 & 0.19 \\
\hline $\operatorname{Li}\left(\mu g \mathrm{~L}^{-1}\right)$ & 0.69 & 0.59 & 0.16 & 0.06 \\
\hline $\mathrm{Ca}\left(\mathrm{mg} \mathrm{L}^{-1}\right)$ & 0.35 & 0.93 & -0.04 & -0.03 \\
\hline Alkalinity $\left(\mathrm{mmol} \mathrm{L}^{-1}\right)$ & 0.38 & 0.90 & -0.07 & -0.09 \\
\hline $\operatorname{Sr}\left(\mu g \mathrm{~L}^{-1}\right)$ & 0.41 & 0.88 & -0.05 & -0.01 \\
\hline $\mathrm{EC}\left(\mathrm{mS} \mathrm{m}^{-1}\right.$ at $\left.25^{\circ} \mathrm{C}\right)$ & 0.46 & 0.84 & -0.05 & 0.26 \\
\hline $\mathrm{pH}$ & 0.04 & 0.84 & -0.27 & -0.26 \\
\hline $\mathrm{NO}_{3}\left(\mathrm{mg} \mathrm{L}^{-1}\right)$ & 0.20 & 0.79 & 0.37 & -0.14 \\
\hline $\mathrm{Na}\left(\mathrm{mg} \mathrm{L}^{-1}\right)$ & 0.20 & -0.06 & -0.05 & 0.94 \\
\hline $\mathrm{Cl}\left(\mathrm{mg} \mathrm{L}^{-1}\right)$ & 0.12 & -0.19 & -0.01 & 0.95 \\
\hline Explained variance & 12.3 & 5.1 & 3.2 & 2.0 \\
\hline$\%$ of explained variance & 43.8 & 18.0 & 11.6 & 7.1 \\
\hline Cumulative $\%$ of variance & 43.8 & 61.8 & 73.4 & 80.5 \\
\hline
\end{tabular}

Table 4. Factor score from principal component loading contributing to each case (observation wells and seasons, where 0412 and 0812 represent samples taken during April 2012 and August 2012, respectively). Positive factor scores are marked as bold.

\begin{tabular}{lrrrr}
\hline Case & \multicolumn{3}{c}{ Principal component (PC) } \\
\hline & 1 & 2 & 3 & 4 \\
\hline Lake water_0812 & -1.33 & -0.06 & $\mathbf{4 . 0 6}$ & -0.24 \\
Obs1_0412 & $\mathbf{0 . 8 4}$ & -1.22 & -0.03 & -0.86 \\
Obs1_0812 & $\mathbf{0 . 3 4}$ & -1.12 & -0.15 & -0.57 \\
Obs2_0412 & $\mathbf{0 . 2 5}$ & -1.00 & $\mathbf{1 . 1 3}$ & -0.71 \\
Obs2_0812 & -0.12 & -0.83 & $\mathbf{0 . 7 5}$ & -0.35 \\
Obs3_0412 & -0.16 & -0.62 & -0.66 & -0.89 \\
Obs4_0412 & -0.44 & -0.40 & -0.86 & -1.13 \\
Obs4_0812 & -0.48 & -0.47 & -0.18 & -0.76 \\
Obs5_0412 & -0.41 & -0.58 & -0.80 & -0.85 \\
Obs6_0812top & -1.34 & $\mathbf{0 . 2 4}$ & -0.58 & $\mathbf{1 . 8 7}$ \\
Obs6_0412mixed & -0.79 & -0.16 & -0.59 & $\mathbf{2 . 4 3}$ \\
Obs6_0812mixed & -0.93 & -0.28 & $\mathbf{0 . 1 5}$ & $\mathbf{2 . 4 1}$ \\
Obs6_0812bottom & -0.66 & -0.39 & -0.36 & -0.16 \\
Obs7_0412 & -0.97 & -0.43 & -0.87 & -0.33 \\
Obs7_0812 & -1.14 & -0.33 & -0.20 & -0.11 \\
Obs8_0412mixed & -0.35 & $\mathbf{1 . 6 0}$ & -0.04 & -0.67 \\
Obs8_0812top & -0.53 & $\mathbf{1 . 8 5}$ & -0.59 & -0.91 \\
Obs8_0812mixed & -0.32 & $\mathbf{1 . 2 2}$ & -0.16 & -0.64 \\
Obs8_0812bottom & -0.46 & $\mathbf{1 . 8 9}$ & -0.74 & -0.49 \\
Obs9_0412 & $\mathbf{1 . 8 0}$ & -0.79 & -0.54 & $\mathbf{0 . 3 7}$ \\
Obs9_0812 & $\mathbf{1 . 2 7}$ & -0.76 & 0.01 & $\mathbf{0 . 7 5}$ \\
Obs10_0412 & $\mathbf{2 . 0 2}$ & $\mathbf{1 . 5 2}$ & $\mathbf{0 . 6 4}$ & $\mathbf{0 . 6 0}$ \\
Obs10_0812 & $\mathbf{1 . 4 8}$ & $\mathbf{1 . 7 4}$ & $\mathbf{0 . 7 4}$ & $\mathbf{0 . 2 6}$ \\
Obs11_0412 & $\mathbf{1 . 3 6}$ & -0.54 & -0.13 & $\mathbf{0 . 3 5}$ \\
Obs11_0812 & $\mathbf{1 . 0 5}$ & -0.10 & -0.01 & $\mathbf{0 . 6 2}$ \\
\hline & & & & \\
\hline
\end{tabular}

\subsection{Spatial distribution of groundwater geochemistry}

which was very small and could have had an origin other than direct seawater intrusion, e.g. atmospheric fallout. However, according to the Piper diagram, sulfate reduction may possibly be observed in Obs11, approx. $60 \mathrm{~m}$ from the coastline. Obs11 is located in a low-lying area with a well head elevation of $0.5 \mathrm{~m}$ a.s.l. Water from this well had the highest $\mathrm{SO}_{4}$ concentration of $38.3 \mathrm{mg} \mathrm{L}^{-1}$, with $\mathrm{CO}_{2}$ and $\mathrm{O}_{2}$ concentrations of 29.0 and $4.1 \mathrm{mg} \mathrm{L}^{-1}$, respectively. Based on the geochemistry of three water samples from this well, $\mathrm{SO}_{4}$ showed a strong negative correlation with $\mathrm{HCO}_{3}(r=0.98)$. Seawater has a high $\mathrm{SO}_{4}$ concentration, and when it intrudes into an aquifer, especially into an anoxic low-lying coastal aquifer, it may result in sulfate reduction (Andersen, 2001; Appelo and Postma, 2005) and have a negative correlation with $\mathrm{HCO}_{3}$. However, the reduction in sulfate combined with the enrichment of bicarbonate in the mixing zone suggests bacterial reactions (Magaritz and Luzier, 1985). The monitoring data indicate that the groundwater level is occasionally lower than the seawater level, either due to overpumping or sea level rise, which could temporarily cause seawater intrusion into the aquifer.

\subsubsection{Principal component analysis (PCA)}

Statistically significant correlations were detected between certain variables and, therefore, principal component analysis (PCA) was conducted (Table 3) in order to group the variables. After Varimax rotation with Kaiser normalisation, four principal components having eigenvalues higher than 1 were chosen, because they explained over $80 \%$ of the total variance observed (Cloutier et al., 2008; IBM SPSS Statistics, 2013). The factor score of each principal component was calculated for each of the samples as shown in Table 4.

$\mathrm{PC} 1$ is characterised by highly positive loading in $\mathrm{SO}_{4}, \mathrm{~K}$, $\mathrm{Ba}, \mathrm{Cu}, \mathrm{Mo}, \mathrm{Mg}, \mathrm{I}, \mathrm{Mn}, \mathrm{Li}$, and $\mathrm{Si}$, explaining $43.8 \%$ of the total variance. The highest scores were found in Obs10, Obs9 and Obs11, and moderate to low positive scores were also observed in Obs1 and Obs2_0412 samples. PC1 mainly indicates the natural groundwater quality, and comprises wells that penetrate the primary deposit of the First Salpausselkä formation (Luoma et al., 2013), together with Obs10 and Obs11 located further in the discharge area. The primary de- 
posit of the First Salpausselkä formation consists of glacial till, gravel, sand and clay of the glaciogenic sediments resulting from the erosion of the pre-existing Precambrian bedrock, e.g. granite, quartz diorite and granodiorites. PC1 reveals the influence of a natural origin on groundwater quality from the dissolution of minerals bearing the aquifer material, such as sulfide, K-feldspar or clay minerals (Lahermo et al., 2002; Shand and Edmunds, 2008). Shotyk et al. (2010) reported high concentrations of $\mathrm{S}, \mathrm{Si}, \mathrm{Ba}, \mathrm{Mg}, \mathrm{Mn}, \mathrm{Li}$ and $\mathrm{Rb}$ in groundwater resulting from weathering of the dominant silicate minerals in sediments of a discharge area in two natural artesian flows in Ontario, Canada.

PC2 has the highest loadings for Ca, alkalinity, pH, EC, $\mathrm{NO}_{3}$ and $\mathrm{Sr}$, explaining $18.0 \%$ of the total variance. It has a highly positive loading in Obs8 and Obs10. A low positive loading was also observed in the Obs6_0812top sample. The variables in PC2 have a strong to very strong positive correlation with each other, especially $\mathrm{Ca}$, alkalinity, $\mathrm{Sr}$ and EC, which have Pearson correlation coefficients among each other of between 0.99 and $0.92(\rho<0.01)$. PC2 is related to the solution of carbonate in the groundwater. Obs8 and Obs 10 contain the highest concentrations of $\mathrm{Ca}, \mathrm{Sr}$ and $\mathrm{EC}$, and are distinct from the other wells in the study area. Obs8 is located next to a gravel pit and a concrete factory, and Obs 10 is located in a downstream direction from Obs8. The excess $\mathrm{Sr}$ associates with $\mathrm{Ca}$ and $\mathrm{HCO}_{3}$ (alkalinity) compared with the surrounding wells, indicating the potential contamination of the groundwater from human activity, similarly to $\mathrm{NO}_{3}$, which has the highest concentrations in Obs8 and Obs10. Although $\mathrm{NO}_{3}$ could be derived from the dissolution of organic matter under reducing conditions, the increases in $\mathrm{NO}_{3}, \mathrm{EC}$ and other dissolved ion concentrations in Obs 10 since 2010 during the sampling period may indicate an anthropogenic effect from human activity taking place in this area.

PC3 explains $11.6 \%$ of the total variance and has a high positive loading in $\mathrm{KMnO}_{4}$ consumption and the stable isotopes $\delta^{2} \mathrm{H}$ and $\delta^{18} \mathrm{O}$. The highest scores were found in lake water and Obs2_0412 samples, and moderate scores in Obs2_0812 and Obs10. PC3 reveals the influences of surface water on the groundwater. The $\mathrm{KMnO}_{4}$ consumption values in groundwater indicate an influence of surface water or dissolved organic matter (Korkka-Niemi, 2001; Lahermo et al., 2002). In many wells, the concentrations of major ions and some other dissolved ions in groundwater were higher in spring samples than in summer samples, while $\mathrm{KMnO}_{4}$ consumption was higher in summer than in spring. Based only on $\mathrm{KMnO}_{4}$ consumption, the influence of surface water should be more clearly observed in summer. However, the $\delta^{2} \mathrm{H}$ and $\delta^{18} \mathrm{O}$ values reveal the possible influence of surface water from the lake in Obs2_0412, but no influence of surface water in Obs2_0812 and Obs10. Obs11 is located closer to the sea shore than Obs10. Based on its location, Obs11 should display a greater influence from seawater than Obs10. However, PC 3 extracted the information existing in Obs10, which has a higher $\mathrm{KMnO}_{4}$ consumption than Obs11 and contributed a higher factor score loading than Obs11. PC3 indicates the influences of surface water or surface waterinduced dissolved organic matter on groundwater quality at Obs10.

PC4 has highly positive loadings in $\mathrm{Na}$ and $\mathrm{Cl}$, and explains $7.1 \%$ of the total variance. The highest scores were found in the mixed and top samples from Obs6, while the Obs6 bottom sample showed a negative score. Moderate to low positive scores were also found in Obs9, Obs10 and Obs11. PC4 indicates the impact of human activities on groundwater quality, such as the influences of road de-icing salt in the top section of Obs6, which is located about $50 \mathrm{~m}$ in a downstream direction from the highway. The median concentrations of $\mathrm{Na}$ and $\mathrm{Cl}$ in Obs9, Obs10 and Obs11 (7.3 and $7.9 \mathrm{mg} \mathrm{L}^{-1}$, respectively) were higher than the background values reported by Lahermo et al. (2002; 4.18 and $4.40 \mathrm{mg} \mathrm{L}^{-1}$, respectively). Sodium and $\mathrm{Cl}$ of those three wells showed a positive correlation with $\mathrm{Ca}$, alkalinity, $\mathrm{Sr}$ and EC, the main factor components found in PC2. PC1 reveals the natural impact on the groundwater quality in Obs9, Obs10 and Obs11, while PC4 may indicate some influences of human activity on these wells.

Overall, PCA is a useful tool for extracting the main components that represent the impacts of both natural and human activities on water quality, either on regional or site-specific scales, and Obs10 has been identified as the most vulnerable well that has been impacted by both natural and human activities.

\subsubsection{Hierarchical cluster analysis (HCA)}

The results of HCA are presented based on the sample locations in the dendrogram in Fig. 7. The clusters were classified based on the linkage distance in the dendrogram, indicating the level of similarity of variables between clusters. The shorter the linkage distance, the higher the similarity of variables between clusters. Based on the linkage distance at 9, the water samples were classified into 6 clusters (C1-C6). C1 consists of Obs3, Obs4, Obs5, Obs6_bottom and Obs7, C2 consists of Obs6_top and Obs6_mixed samples, and C3 consists of Obs1, Obs2 and lake water. C4 consists of all samples from Obs8, C5 of samples from Obs10, and C6 consists of Obs9 and Obs11. The median values of the main variables in each cluster (excluding lake water) are summarised in Table 5 .

$\mathrm{C} 1, \mathrm{C} 2$ and $\mathrm{C} 3$ comprise lower median values of variables compared with $\mathrm{C} 4, \mathrm{C} 5$ and $\mathrm{C} 6$. The main differences between $\mathrm{C} 1, \mathrm{C} 2$ and $\mathrm{C} 3$ are that $\mathrm{C} 2$ contains the highest $\mathrm{Na}$ and $\mathrm{Cl}$ concentrations compared to the others, and $\mathrm{C} 3$ contains the highest concentrations of $\mathrm{Al}$ and $\mathrm{KMnO}_{4}$ consumption. These clusters consist of wells that are located in the groundwater recharge area in the middle of the aquifer, and could be grouped into the same cluster. However, with the classification based on the linkage distance at 9, C2 could emphasise the influences of de-icing with road salt in the top section of 
Table 5. Median values of variables in each cluster from groundwater samples $(n=24)$ taken during spring (April) and summer (August) 2012.

\begin{tabular}{|c|c|c|c|c|c|c|}
\hline Cluster & 1 & 2 & 3 & 4 & 5 & 6 \\
\hline Number of samples & 7 & 3 & 4 & 4 & 2 & 4 \\
\hline $\mathrm{Eh}(\mathrm{mV})$ & 292 & 312 & 273 & 201 & 267 & 219 \\
\hline $\mathrm{O}_{2}\left(\mathrm{mg} \mathrm{L}^{-1}\right)$ & 11.3 & 8.77 & 5.89 & 5.79 & 1.20 & 2.68 \\
\hline $\mathrm{CO}_{2}\left(\mathrm{mg} \mathrm{L}^{-1}\right)$ & 3.0 & 13.0 & 18.0 & 1.5 & 16.0 & 31.0 \\
\hline $\mathrm{pH}$ & 6.6 & 6.2 & 5.7 & 7.8 & 7.1 & 6.6 \\
\hline $\mathrm{EC}\left(\mathrm{mS} \mathrm{m}^{-1}\right.$ at $\left.25^{\circ} \mathrm{C}\right)$ & 4.74 & 12.9 & 4.79 & 22.7 & 29.9 & 15.3 \\
\hline Alkalinity $\left(\mathrm{mmol} \mathrm{L}^{-1}\right)$ & 0.22 & 0.23 & 0.16 & 2.06 & 2.17 & 0.84 \\
\hline $\mathrm{KMnO}_{4}\left(\mathrm{mg} \mathrm{L}^{-1}\right)$ & 0.6 & 1.8 & 4.90 & 1.5 & 5.0 & 1.9 \\
\hline $\mathrm{K}\left(\mathrm{mg} \mathrm{L}^{-1}\right)$ & 0.55 & 0.59 & 0.66 & 0.94 & 4.19 & 1.88 \\
\hline $\mathrm{Ca}\left(\mathrm{mg} \mathrm{L}^{-1}\right)$ & 4.28 & 8.00 & 3.33 & 38.5 & 45.2 & 14.1 \\
\hline $\operatorname{Mg}\left(\mathrm{mg} \mathrm{L}^{-1}\right)$ & 0.93 & 1.40 & 0.85 & 1.96 & 2.82 & 3.56 \\
\hline $\mathrm{Na}\left(\mathrm{mg} \mathrm{L}^{-1}\right)$ & 2.46 & 12.7 & 2.94 & 2.41 & 6.63 & 7.89 \\
\hline $\mathrm{Cl}\left(\mathrm{mg} \mathrm{L}^{-1}\right)$ & 2.78 & 25.0 & 3.21 & 1.95 & 5.48 & 8.47 \\
\hline $\mathrm{SO}_{4}\left(\mathrm{mg} \mathrm{L}^{-1}\right)$ & 7.18 & 8.40 & 8.60 & 8.22 & 29.3 & 17.0 \\
\hline $\mathrm{NO}_{3}\left(\mathrm{mg} \mathrm{L}^{-1}\right)$ & $<0.20$ & 0.30 & 0.90 & 2.95 & 5.40 & 0.39 \\
\hline $\mathrm{Si}\left(\mathrm{mg} \mathrm{L}^{-1}\right)$ & 5.37 & 5.70 & 7.15 & 4.73 & 6.52 & 8.87 \\
\hline $\mathrm{F}\left(\mathrm{mg} \mathrm{L}^{-1}\right)$ & $<0.10$ & $<0.10$ & 0.11 & $<0.10$ & 0.40 & 0.53 \\
\hline $\operatorname{Sr}\left(\mu g \mathrm{~L}^{-1}\right)$ & 15.5 & 29.9 & 20.9 & 131.0 & 144.5 & 64.6 \\
\hline $\mathrm{I}(\mu \mathrm{g} \mathrm{L}-1)$ & 3.69 & 3.27 & 3.14 & 5.68 & 14.5 & 10.3 \\
\hline $\operatorname{Li}\left(\mu g \mathrm{~L}^{-1}\right)$ & 0.61 & 0.16 & 0.14 & 2.05 & 6.10 & 2.61 \\
\hline $\operatorname{Mn}\left(\mu g L^{-1}\right)$ & 0.25 & 1.22 & 17.3 & 0.15 & 48.5 & 21.6 \\
\hline $\mathrm{Cu}\left(\mu \mathrm{gL}^{-1}\right)$ & $<0.10$ & $<0.10$ & 0.52 & 0.44 & 3.55 & 0.79 \\
\hline $\mathrm{Al}\left(\mu \mathrm{g} \mathrm{L}^{-1}\right)$ & 8.02 & 13.8 & 121.3 & 3.95 & 1.68 & 35.8 \\
\hline As $\left(\mu \mathrm{gL}^{-1}\right)$ & 0.10 & $<0.05$ & 0.10 & 0.47 & 0.79 & 0.18 \\
\hline $\mathrm{B}\left(\mu \mathrm{g} \mathrm{L}^{-1}\right)$ & 11.3 & 5.69 & 9.43 & 5.93 & 14.0 & 15.0 \\
\hline $\mathrm{Ba}\left(\mu \mathrm{g} \mathrm{L}^{-1}\right)$ & 1.30 & 3.14 & 5.01 & 1.64 & 14.7 & 7.25 \\
\hline $\mathrm{Cr}\left(\mu \mathrm{g} \mathrm{L}^{-1}\right)$ & $<0.20$ & $<0.20$ & 0.25 & 0.60 & 0.29 & $<0.20$ \\
\hline $\operatorname{Mo}\left(\mu \mathrm{gL}^{-1}\right)$ & 0.14 & 0.09 & 0.28 & 0.45 & 2.08 & 0.55 \\
\hline
\end{tabular}

Obs6, and $\mathrm{C} 3$ the influence of lake water on groundwater in Obs2 and Obs1. C2 and $\mathrm{C} 3$ are in agreement with PC4 and PC3, respectively, except that PC3 shows no principal component loading for Obs1.

C4, C5 and C6 consist of wells located closer to the groundwater discharge and areas of human activity. Some dissolved ions in groundwater found in $\mathrm{C} 4$ were quite low and close to $\mathrm{C} 1, \mathrm{C} 2$ and $\mathrm{C} 3$, but elevated concentrations of $\mathrm{Ca}, \mathrm{HCO}_{3}, \mathrm{Sr}, \mathrm{EC}, \mathrm{pH}$ and $\mathrm{NO}_{3}$ linked it to $\mathrm{C} 5$, which indicates the impact of human activities from the gravel excavation pit and the concrete factory. C5 and C6 contain higher dissolved solute concentrations than the other clusters and are linked together due to sharing the same or similar natural origin and probably also some influences from human activities. C4 and C5 are consistent with PC2, and PC5 and PC6 are consistent with PC1.

Well-proven PCA and HCA approaches have been used before in order to determine natural components affecting groundwater quality (e.g. Cloutier et al., 2008; Güler et al., 2002). In this study, the integration of PCA and HCA with conventional classification of groundwater types, and the hydrogeochemical data, provided useful tools for classifying groundwater samples based on the main (natural or anthropogenic) variable components that may influence the geochemistry of groundwater in Finland as performed also by Korkka-Niemi (2001). Moreover, this integration seems to be suitable for identifying the vulnerable groundwater areas impacted by both natural and human activities on water quality, and the results could contribute to the groundwater vulnerability assessments of the coastal aquifers (Ferguson and Gleeson, 2012).

\subsection{Temporal variability in groundwater geochemistry}

Temporal variations in dissolved solute concentrations in groundwater were examined for all groundwater samples between different seasons: spring (April) 2010, spring (April) 2012 and summer (August) 2012. Only data from four observation wells (Obs1, Obs8, Obs10 and Obs11) were available for all three seasons. The annual precipitation of 2012 was exceptionally high, being about $41 \%$ higher than the mean 
Table 6. Changes in selected dissolved concentrations (\%) between seasons in different observation well locations. Numbers in the first row (1 to 11 ) represent observation well numbers (Obs1 to Obs11). Positive numbers are marked as bold, which indicates an increase in dissolved concentrations.

\begin{tabular}{|c|c|c|c|c|c|c|c|c|c|c|c|c|c|c|c|c|c|}
\hline \multirow[t]{2}{*}{ Variable } & \multicolumn{4}{|c|}{ Aril 2010 to April 2012} & \multicolumn{4}{|c|}{ Aril 2010 to August 2012} & \multicolumn{9}{|c|}{ Aril 2012 to August 2012} \\
\hline & 1 & 8 & 10 & 11 & 1 & 8 & 10 & 11 & 1 & 8 & 10 & 11 & 2 & 6 & 4 & 9 & 7 \\
\hline $\mathrm{pH}$ & 9 & 4 & 3 & 16 & 5 & 4 & 3 & 17 & -3 & 0 & 0 & 1 & -2 & -2 & -1 & -3 & -2 \\
\hline $\mathrm{EC}$ & 23 & 67 & 4 & -9 & 13 & -3 & 39 & 7 & -8 & -17 & 2 & 7 & -4 & -12 & 5 & -3 & 1 \\
\hline $\mathrm{KMnO}_{4}$ & -47 & 23 & -26 & -57 & -73 & 46 & 15 & 33 & -49 & 19 & 56 & 54 & 14 & 556 & 200 & 28 & 66 \\
\hline Alkalinity & 21 & 102 & 7 & 46 & 36 & 63 & 14 & 61 & 12 & -19 & 6 & 10 & 40 & 10 & 27 & -7 & 13 \\
\hline $\mathrm{Ca}$ & 8 & 75 & 1 & -12 & -2 & 48 & 9 & 1 & -9 & -15 & 8 & 15 & -5 & -19 & 4 & -12 & -4 \\
\hline $\mathrm{Mg}$ & 10 & 16 & 33 & -4 & -1 & 6 & 7 & 0 & -10 & -9 & -20 & 4 & -10 & -17 & 0 & -12 & -5 \\
\hline K & -1 & 2 & 2 & -16 & -43 & -34 & -26 & -25 & -42 & -35 & -27 & -11 & -27 & -36 & -21 & -31 & -15 \\
\hline $\mathrm{Na}$ & 9 & -14 & 2 & -4 & 5 & -4 & -39 & -9 & -3 & 12 & -40 & -5 & -4 & -14 & 0 & -5 & 0 \\
\hline $\mathrm{Cl}$ & -6 & -31 & -25 & -3 & -11 & -8 & -35 & 10 & -5 & 34 & -13 & 13 & -22 & -12 & 13 & 19 & 3 \\
\hline $\mathrm{NO}_{3}$ & -24 & -29 & -42 & 45 & -31 & -34 & 6 & 100 & -9 & -8 & 84 & 38 & 2 & -32 & -73 & 0 & -52 \\
\hline $\mathrm{SO}_{4}$ & 22 & -9 & 19 & -42 & 4 & -7 & -5 & -48 & -14 & 2 & -20 & -10 & 3 & -8 & 6 & -6 & -6 \\
\hline $\mathrm{Al}$ & 107 & -72 & -45 & -58 & -2 & -85 & -71 & -88 & -53 & -47 & -46 & -72 & -33 & -32 & 100 & -53 & -62 \\
\hline $\mathrm{Mn}$ & -33 & -93 & 283 & -60 & -66 & -53 & -23 & -80 & -49 & 586 & -80 & -50 & -41 & 150 & 800 & -59 & 60 \\
\hline $\mathrm{Sr}$ & 22 & 85 & -9 & -11 & -16 & 26 & -13 & -8 & -31 & -32 & -5 & 4 & -32 & -34 & -13 & -23 & -11 \\
\hline $\mathrm{F}$ & 200 & 0 & 0 & 22 & 0 & -50 & -40 & 0 & -67 & -50 & -40 & -18 & -55 & -77 & 0 & -35 & -58 \\
\hline $\mathrm{Fe}$ & 29 & -67 & 0 & 0 & -58 & -67 & 0 & 0 & -68 & 0 & 0 & 0 & -20 & 0 & 0 & -67 & 0 \\
\hline $\mathrm{P}$ & 0 & 0 & 116 & 0 & 360 & 0 & 180 & 0 & 360 & 0 & 30 & 0 & 0 & 0 & 460 & 0 & 0 \\
\hline $\mathrm{Si}$ & 15 & -6 & 17 & -11 & 8 & -1 & 13 & -13 & -6 & 5 & -4 & -3 & 3 & 2 & 1 & -6 & 1 \\
\hline $\mathrm{Cd}$ & 60 & 0 & 100 & -42 & 60 & 0 & 50 & -58 & 0 & 0 & -25 & -29 & 25 & 50 & 100 & -17 & 0 \\
\hline Co & 34 & 488 & 367 & -48 & -8 & -37 & 167 & -81 & -31 & -89 & -43 & -64 & -37 & -56 & -97 & -46 & -97 \\
\hline $\mathrm{Cr}$ & 0 & -42 & 220 & 100 & 0 & 72 & 150 & 0 & 0 & 195 & -22 & -50 & 67 & 0 & 0 & 0 & 0 \\
\hline $\mathrm{Cu}$ & -38 & -42 & 16 & -42 & -51 & -59 & 54 & -28 & -22 & -31 & 34 & 24 & -26 & 0 & 240 & 72 & 0 \\
\hline $\mathrm{Ni}$ & 36 & -37 & 587 & -42 & -40 & 120 & 158 & -78 & -56 & 251 & -62 & -62 & -84 & -88 & -85 & -50 & -77 \\
\hline $\mathrm{Pb}$ & -58 & 260 & 0 & 0 & -58 & 0 & 140 & 340 & 0 & -72 & 140 & 340 & -63 & 143 & 340 & 260 & 100 \\
\hline
\end{tabular}

annual precipitation of 1981-2010, and it was the highest recorded precipitation since 1963 (FMI, 2013). The annual precipitation from April 2011 to April 2012 (876 mm) was $322 \mathrm{~mm}$ higher than the period April 2009 to April 2010 (554 mm). In 2012, groundwater reached the highest level in April 2012, immediately after snowmelt. However, the amount of precipitation continued to increase during June to the end of the year due to the increase in heavy rain events during that period (Fig. 2). The percentage changes between seasons in the concentrations of selected dissolved elements in different observation well locations are presented in Table 6 . A positive number indicates an increase in dissolved concentrations. Table 6 indicates the variations in the amount of precipitation or timing of recharge in different seasons, which has an effect on groundwater quality. However, the aquifer area has mostly received the same amount of precipitation at a time, and the dissolved concentrations of elements in groundwater have varied spatially in different well locations. Overall, the concentrations of $\mathrm{Ca}, \mathrm{HCO}_{3}, \mathrm{EC}$, and $\mathrm{KMnO}_{4}$ consumption increased in most wells with an increase in precipitation. Obs6 and Obs4 showed very high variations in $\mathrm{KMnO}_{4}$ consumption relative to the other wells. An increase in $\mathrm{KMnO}_{4}$ consumption implies the influences of surface water or dissolved organic matter (Korkka-Niemi, 2001; Lahermo et al., 2002).
Obs10 had higher EC and dissolved ion concentrations than the other wells, and $\mathrm{EC}, \mathrm{Ca}, \mathrm{HCO}_{3}$, and $\mathrm{KMnO}_{4}$ consumption has increased since April 2010, while the $\mathrm{Cl}$ concentration has decreased. Obs10 contained the highest $\mathrm{NO}_{3}$ concentration, although an increasing concentration of $\mathrm{NO}_{3}$ since April 2010 was observed in Obs11, downstream from Obs10. In addition, Obs10 showed an increase in metal concentrations in groundwater following the increase in precipitation since April 2010. Okkonen and Kløve (2011) and Korkka-Niemi (2001) reported a decrease in the concentration of $\mathrm{NO}_{3}$ in groundwater during the spring, when recharge from snowmelt occurs. In contrast, high $\mathrm{NO}_{3}$ concentrations in spring and autumn were found due to increased nitrogen leaching associated with the increase in runoff from forests (Lepistö, 1996) and drained peatlands (Kløve, 2001).

The concentrations of $\mathrm{Fe}, \mathrm{Al}, \mathrm{Mn}$, and $\mathrm{SO}_{4}$ were occasionally high during spring, immediately after the snowmelt (both in April 2010 and April 2012). However, their concentrations were highly variable and often associated with low $\mathrm{pH}$ values observed in Obs1, Obs2, Obs4 and Obs11. Iron, $\mathrm{Mn}$ and $\mathrm{SO}_{4}$ are redox-sensitive elements in groundwater and are soluble under reducing conditions (Hem, 1985; Shand and Edmunds, 2008). High concentrations of Al can be associated with clay minerals or organic matter, and Al 


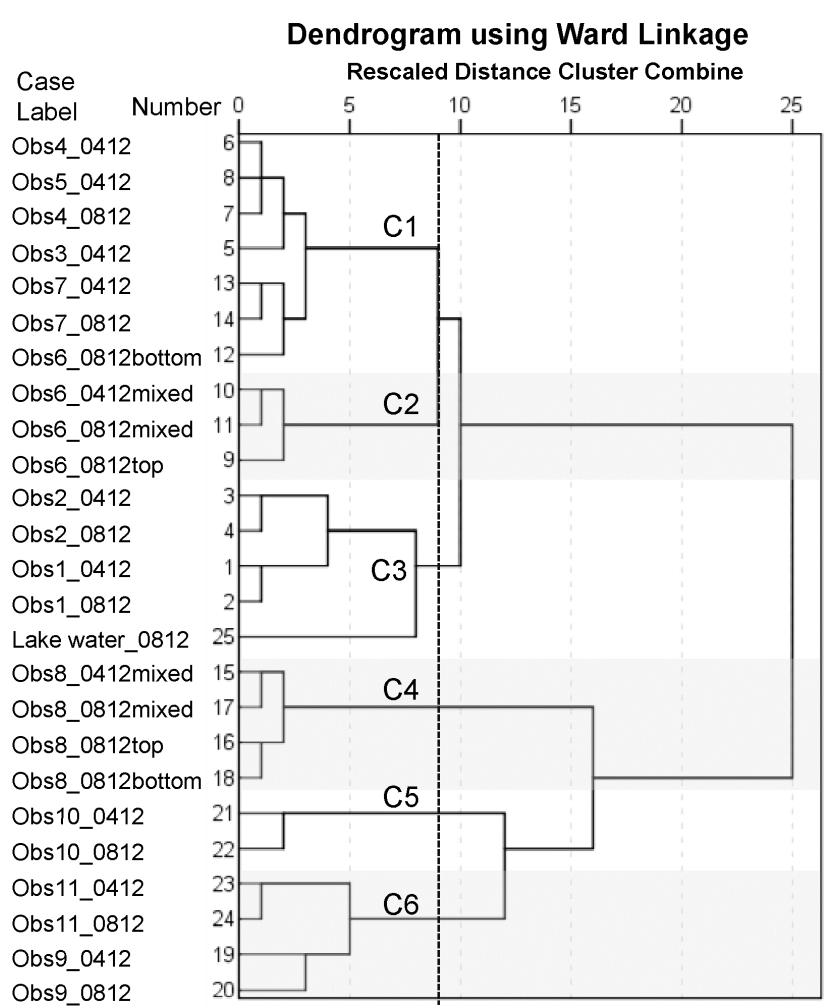

Figure 7. Hierarchical clustering results (dendrogram) of water samples $(n=25)$ taken during spring (April) and summer (August) 2012.

had a high positive correlation with $\mathrm{KMnO}_{4}$ consumption, with a Pearson correlation coefficient of $0.79(\rho<0.01)$.

Based on the future climate scenarios A1B and B1, by the end of 2100 , precipitation in the Hanko area is expected to increase by $12-26 \%$ compared with the current situation and the sea level will rise by up to $0.51 \mathrm{~m}$ above the current mean sea level (Luoma and Okkonen, 2014). The potential increase in precipitation during the autumn and winter in the future could cause more freshwater to enter the aquifer and possibly a greater influence of seawater intrusion due to the sea level rise and storm surges. Based on the observed seasonal variation, an increase in the concentrations of some dissolved elements, as mentioned earlier, and changes in the groundwater geochemistry of wells along the coastline, can be expected.

\section{Conclusions}

This study clearly demonstrated that the geochemistry of groundwater in the shallow, unconfined, low-lying coastal aquifer in Santala has spatial and temporal variability depending on the geological, anthropogenic, seawater and climate factors. The groundwater is mainly of the $\mathrm{Ca}-\mathrm{HCO}_{3}$ type, with low dissolved element concentrations, low $\mathrm{pH}$, alkalinity, $\mathrm{Ca}$ and $\mathrm{Mg}$ concentrations due to rapid percolation or a short residence time. An important finding was that the groundwater geochemistry of the coastal aquifer in Santala was generally very similar to that of inland shallow aquifers in Finland. The stable isotopes $\delta^{2} \mathrm{H}$ and $\delta^{18} \mathrm{O}$ clearly suggest that the Santala aquifer recharges directly from meteoric water (snowmelt and rainfall), with minor or insignificant contributions from the Baltic Sea and the lake above the aquifer. However, the high temporal and spatial variability of the stable isotopes from wells near the gravel excavation pit and the lake indicate the direct influence of surface water, indicating local mixing between groundwater and surface water within the aquifer. This was observed from the increases in $\mathrm{KMnO}_{4}$ consumption in wells near the lake. While both $\delta^{2} \mathrm{H}$ and $\delta^{18} \mathrm{O}$ provided no evidence of seawater intrusion in the aquifer, the geochemistry of groundwater suggests sulfate reduction in the mixed zone between freshwater and seawater, indicating that local seawater intrusion may temporarily take place. Although the salinity of the Baltic Sea is low, the groundwater pumping wells need to be carefully positioned and the pumping rates well managed to avoid such a mixing zone. The findings also showed that the use of stable isotopes $\delta^{2} \mathrm{H}$ and $\delta^{18} \mathrm{O}$ alone to identify seawater-aquifer interaction is not sufficient to determine the rate of water exchange.

The geochemistry of groundwater in the Santala aquifer varies spatially and temporally according to changes in the hydrological conditions, such as precipitation events and snowmelt. The concentrations of $\mathrm{Ca}$ and $\mathrm{HCO}_{3}, \mathrm{EC}$, and $\mathrm{KMnO}_{4}$ consumption increased in most monitored wells with an increase in precipitation, while the concentrations of $\mathrm{Fe}, \mathrm{Al}, \mathrm{Mn}$, and $\mathrm{SO}_{4}$ were occasionally higher soon after snowmelt. The PCA and HCA multivariate statistical approaches yielded similar results. Those are useful tools to extract the main components that are able to identify the vulnerable areas of the coarse grained glaciogenic aquifer impacted by natural or human activities, either on regional or site-specific scales. In coastal aquifers with low hydraulic gradients, the hydrogeochemistry should be used to confirm the intrusion of seawater.

Based on the future climate scenarios, precipitation in the Hanko area is expected to increase, as well as the Baltic Sea level. This could cause increased recharge of the aquifer from surface water, but also some seawater intrusion due to the sea level rise and storm surges as well as increased groundwater abstraction. An increase in the concentrations of some dissolved elements and changes in groundwater geochemistry along the coastline can be expected in the future. The integration of PCA and HCA with conventional classification of groundwater types, as well as with the hydrogeochemical data, provided an understanding of complex groundwater flow systems for the aquifer vulnerability assessment and groundwater management in the future.

The approach used in this study could be applied in the other low-lying coastline aquifers worldwide, including the Baltic Sea region such as in Finland, where approximately 300 of the total classified 6000 Finnish shallow groundwa- 
ter aquifers are located less than $100 \mathrm{~m}$ from the Baltic Sea shoreline.

Acknowledgements. This study was supported by the Groundwater Research Program at Geological Survey of Finland (GTK) and parts of the data were received from the BaltCICA (Climate Change: Impacts, Costs and Adaptation in the Baltic Sea Region) project, which was partly financed by the European Union in the Baltic Sea Region Programme 2007-2013. We would like to thank Hanko Water and Wastewater Works, Esko Nylander, and Visko TeePak Oy, for providing us with the background reports, Arto Pullinen for his help in the field work, and Arja Henttinen for her help in the isotope analysis.

Edited by: P. Wachniew

\section{References}

Alenius, P., Myrberg, K., and Nekrasov, A.: The physical oceanography of the Gulf of Finland: a review, Boreal Environ. Res., 3, 97-125, 1998.

Allen, D. M.: Sources of groundwater salinity on islands using ${ }^{18} \mathrm{O}$, ${ }^{2} \mathrm{H}$, and ${ }^{34} \mathrm{~S}$, Ground Water, 42, 17-31, 2004.

Andersen, M. S.: Geochemical processes at a seawater-freshwater interface, PhD Thesis, Technical University of Denmark, Kgs. Lyngby, 2001.

Appelo, C. A. and Postma, D.: Geochemistry, groundwater and pollution, A.A. Balkema Publishers, Leiden, the Netherlands, 2005.

Backman, B.: Groundwater quality, acidification, and recovery trends between 1969 and 2002 in South Finland, Bulletin 401, Geological Survey of Finland, Espoo, 2004.

Backman, B., Lahermo, P., Väisänen, U., Paukola, T., Juntunen, R., Karhu, J., Pullinen, A., Rainio, H., and Tanskanen, H.: Geologian ja ihmisen toiminnan vaikutus pohjaveteen, Seurantatutkimuksen tulokset vuosilta 1969-1996, Summary: The effect of geological environment and human activities on groundwater in Finland, Results of monitoring in 1969-1996, Report of Investigations 147, Geological Survey of Finland, Espoo, 1999.

Backman, B., Luoma, S., Schmidt-Thomé, P., and Laitinen, J.: Potential risks for shallow groundwater aquifers in coastal areas of the Baltic Sea, a case study in Hanko area in south Finland, CIVPRO Working Paper 2007: 2, Geological Survey of Finland, Espoo, 2007.

Barlow, P. M.: Ground water in fresh water-salt water environments of the Atlantic Coast, U.S. Geological Survey circular 1262, 2003.

Clark, I. D. and Fritz, P.: Environmental Isotopes in Hydrology, CRC Press, Lewis Publishers, Boca Raton, Florida, 1997.

Cloutier, V., Lefebvre, R., Therrien, R., and Savard, M. M.: Multivariate statistical analysis of geochemical data as indicative of the hydrogeochemical evolution of groundwater in a sedimentary rock aquifer system, J. Hydrogeol., 353, 294-313, 2008.

Csuros, M.: Environmental sampling and analysis for technicians, Lewis Publishers/CRC Press Boca Raton, Florida, USA, 1994.

Drever, J. I.: The geochemistry of natural waters, Surface and Groundwater Environments, 3rd Edn., Prentice - Hall, 1997.

EEA: Groundwater quality and quantity in Europe, edited by: Nixon, S., European Environment Agency, Copenhagen, 1999.
Fagerlund, G.: Chloride transport and reinforcement corrosion in concrete exposed to sea water pressure, Division of Building Materials, Lund University, 2008.

Faure, G. and Mensing, T. M.: Isotopes: Principles and Applications, Wiley, John and Sons, Incorporated, 2005.

Ferguson, G. and Gleeson, T.: Vulnerability of coastal aquifers to groundwater use and climate change, Nat. Clim. Change, 2, 342345, doi:10.1038/nclimate1413, 2012.

FMI: Finnish Meteorological Institute (FMI), available at: http:// www.fmi.fi, last access: 20 March 2013.

Fyfe, G. J.: The morphology and sedimentology of the Salpausselkä I Moraine in southwest Finland, Cambridge University: Fitzwilliam College, 1991.

Gonfiantini, R.: Environmental isotopes in lake studies, in: Handbook of Environmental Isotope Geochemistry, edited by: Fritz, P. and Fontes, J. C., The Terrestrial Environment B, 2, Elsevier, Amsterdam, 113-168, 1986.

Güler, C., Thyne, G. D., McCray, J. E., and Turner, A. K.: Evaluation of graphical and multivariate statistical methods for classification of water chemistry data, J. Hydrogeol., 10, 455-474, 2002.

Gustafsson, J. and Nystén, T.: Trends of chloride concentration in groundwater and results of risk assessment of road salting in Finland, in: Ground Water 2000: Proceedings of the International Conference on Ground Water Research, edited by: Bjerg, P., Engesgaard, P., and Krom, T., Copenhagen, Denmark, A.A. Balkema, Rotterdam, the Netherlands, 249-251, 2000.

Harbison, J. E.: Groundwater chemistry and hydrological processes within a Quaternary coastal plain: Pimpama, Southeast Queensland, PhD Thesis, Queenland University of Technology, 2007.

Hem, J. D.: Study and Interpretation of the Chemical Characteristics of Natural Water, 3rd Edn., Alexandria, VA: Department of the Interior, U.S. Geologcial Survey Water Supply Paper 2254, 1985.

Hendriksson, N., Saraperä, S., and Artimo, A.: Stable isotopes in monitoring artificial recharge and validating 3D groundwater flow model results - congress program and abstracts, The 39th International Association of Hydrogeologists Congress, 16-21 September 2012, Niagara Falls, Canada, 402-403, 2012.

Hertta Database-SYKE: HERTTA - Environmental information data systems from Finnish Environment Institute (SYKE), available at: http://www.ymparisto.fi/, last access: 27 November 2013.

IBM SPSS Statistics: Data and Statistical Analysis Software System Version 21, 2013.

IPCC: Emissions Scenarios: Summary for Policymakers - A Special Report of IPCC Working Group III, 2000.

IPCC: Summary for Policymakers, in: Climate Change 2007: Impacts, Adaptation and Vulnerability, Contribution of Working Group II to the Fourth Assessment Report of the Intergovernmental Panel on Climate Change, edited by: Parry, M. L., Canziani, O. F., Palutikof, J. P., Van der Linden, P. J., and Hanson, C. E., Cambridge University Press, Cambridge, UK, 7-22, 2007.

Järvinen, O. and Vänni, T.: Sadeveden pitoisuus- ja laskeuma-arvot Suomessa vuonna 1994 (Concentrations of rainwater and deposition values in Finland during 1994), Finnish Environment Institute (SYKE), 1996 (in Finnish).

Järvinen, O. and Vänni, T.: Sadeveden pitoisuus- ja laskeuma-arvot Suomessa vuonna 1995 (Concentrations of rainwater and deposition values in Finland during 1995), Finnish Environment Institute (SYKE), 1997 (in Finnish). 
Jyrkama, I. M. and Sykes, J. F.: The impact of climate change on spatially varying groundwater recharge in the grand river watershed (Ontario), J. Hydrol., 338, 237-250, 2007.

Kendall, C. and McDonnell, J. J. (Eds.): Isotope tracers in catchment hydrology, Elsevier, the Netherlands, 1998.

Kielosto, S., Kukkonen, M., Sten, C. G., and Backman, B.: Hangon ja Perniön kartta-alueiden maaperä, English summary: Quaternary deposits in the Hanko and Perniö map-sheet areas, Geological map of Finland 1: 100 000, Explanation to the maps of Quaternary deposits, sheets 2011 and 2012, Geological Survey of Finland, Espoo, 1996.

Kløve, B.: Characteristics of nitrogen and phosphorus loads in peat mining wastewater, Water Res., 35, 2353-2362, 2001.

Korkka-Niemi, K.: Cumulative geological, regional and sitespecific factors affecting groundwater quality in domestic wells in Finland, Monographs of the Boreal Environment Research, 20, 2001.

Kortelainen, N.: Isotopic fingerprints in surficial waters: stable isotope methods applied in hydrogeological studies, Geological Survey of Finland, PhD Thesis, Department of Geology, Faculty of Science, Helsinki University, Finland, 2007.

Kortelainen, N.: Isotopic composition of atmospheric precipitation and shallow groundwater in Olkiluoto: O-18, H-2 and H-3, Working Report 2009-06, Olkiluoto, Posiva, 2009.

Kortelainen, N. M. and Karhu, J. A.: Regional and seasonal trends in the oxygen and hydrogen isotope ratios of Finnish groundwaters: a key for mean annual precipitation, J. Hydrol., 285, 143-157, 2004.

Kortelainen, N. and Karhu, J. A.: Tracing the decomposition of dissolved organic carbon in artificial groundwater recharge using carbon isotope ratios, Appl. Geochem., 21, 547-562, 2006.

Lahermo, P., Tarvainen, T., Hatakka, T., Backman, B., Juntunen, R., Kortelainen, N., Lakomaa, T., Nikkarinen, M., Vesterbacka, P., Väisänen, U., and Suomela, P.: Tuhat kaivoa- Suomen kaivovesien fysikaalis-kemiallinen laatu vuonna 1999 (Summary: One thousand wells-the physical-chemical quality of Finnish well waters in 1999), Report of Investigation 155, Geological Survey of Finland, Espoo, 2002.

Lepistö, A.: Hydrological processes contributing to nitrogen leaching from forested catchments in Nordic conditions, Monogr. Boreal Environ. Res. 1, 1-71, 1996.

Luoma, S. and Okkonen, J.: Impacts of Future Climate Change and Baltic Sea Level Rise on Groundwater Recharge, Groundwater Levels, and Surface Leakage in the Hanko Aquifer in Southern Finland, Water, 6, 3671-3700, doi:10.3390/w6123671, 2014.

Luoma, S. and Pullinen, A.: Field Investigation and Estimates of Hydraulic Conductivity from Slug Tests in the First Salpausselkä formation in the Santala area, Hanko, south Finland, Archived report, Geological Survey of Finland, Espoo, 2011.

Luoma, S., Klein, J., and Backman, B.: Climate change and groundwater: Impacts and Adaptation in shallow coastal aquifer in Hanko, south Finland, in: Climate Change Adaptation in Practice - From Strategy Development to Implementation, edited by: Schmidt-Thomé, P. and Klein, J., Wiley-Blackwell, ISBN: 9780470977002 137-155, 2013.

Luoma, S. and Okkonen, J.: Impacts of Future Climate Change and Baltic Sea Level Rise on Groundwater Recharge, Groundwater Levels, and Surface Leakage in the Hanko Aquifer in Southern Finland, Water, 6, 3671-3700, doi:10.3390/w6123671, 2014.
Magaritz, M. and Luzier, J. E.: Water-rock interactions and seawater-freshwater mixing effects in the coastal dunes aquifer, Coos Bay, Oregon, Geochim. Cosmochim. Acta, 49, 2515-2525, 1985.

Mongelli, G., Monni, S., Oggiano, G., Paternoster, M., and Sinisi, R.: Tracing groundwater salinization processes in coastal aquifers: a hydrogeochemical and isotopic approach in the $\mathrm{Na}-\mathrm{Cl}$ brackish waters of northwestern Sardinia, Italy, Hydrol. Earth Syst. Sci., 17, 2917-2928, doi:10.5194/hess-17-29172013, 2013.

Nicholls, R. J., Wong, P. P., Burkett, V. R., Codignotto, J. O., Hay, J. E., McLean, R. F., Ragoonaden, S., and Woodroffe, C. D.: Coastal systems and low-lying areas, Climate Change 2007: Impacts, Adaptation and Vulnerability, Contribution of Working Group II to the Fourth Assessment Report of the Intergovernmental Panel on Climate Change, edited by: Parry, M. L., Canziani, O. F., Palutikof, J. P., Van der Linden, P. J., and Hanson, C. E., Cambridge University Press, Cambridge, UK, 315-356, 2007.

Okkonen, J.: Groundwater and its response to climate variability and change in cold snow dominated regions in Finland: Methods and Estimations, PhD Thesis, University of Oulu, Finland, 2011.

Okkonen, J. and Kløve, B.: Assessment of temporal and spatial variation in chemical composition of groundwater in an unconfined esker aquifer in the cold temperature climate of Northern Finland, Cold Reg. Sci. Technol., 71, 118-128, 2012.

Oude Essink, G. H. P.: Impact of sea-level rise in the Netherlands, in: Seawater Intrusion in Coastal Aquifers: Concepts, Methods and Practices, Theory and Applications of transport in Porous Media, edited by: Bear, J., Cheng, A. H. D., Sore, S., Quasar, D., and Herrera, I., Kluwer Academy, Norwell, Massachusetts, 507-530, 1999.

Oude Essink, G. H. P.: Improving fresh groundwater supplyproblems and solutions, Ocean Coast. Manage., 44, 429-449, 2001.

Oude Essink, G. H. P., Van Baaren, E. S., and De Louw, P. G. B.: Effects of climate change on coastal groundwater systems: A modeling study in the Netherlands, Water Resour. Res., 46, W00F04, doi:10.1029/2009WR008719, 2010.

Piper, A. M.: A graphic procedure in the geochemical interpretation of water analyses, American Geophysical Union Transactions, 25, 914-923, 1944.

Pulido-Leboeuf, P.: Seawater intrusion and associated processes in a small coastal complex aquifer (Castell de Ferro, Spain), Appl. Geochem., 19, 1517-1527, 2004.

Rasmussen, P., Sonnenborg, T. O., Goncear, G., and Hinsby, K.: Assessing impacts of climate change, sea level rise, and drainage canals on saltwater intrusion to coastal aquifer, Hydrol. Earth Syst. Sci., 17, 421-443, doi:10.5194/hess-17-421-2013, 2013.

Rautio, A. and Korkka-Niemi, K.: Characterization of groundwaterlake water interactions at Pyhäjärvi, a lake in SW Finland, Boreal Environ. Res., 16, 363-380, 2011.

Richter, B. C. and Kreitler, C. W.: Geochemical Techniques for Identifying Sources of Ground water Salinization, CRC Press, Inc. Boca Raton, Florida, 1993.

Saarnisto, M. and Saarinen, T.: Deglaciation chronology of the Scandinavian Ice Sheet from the Lake Onega basin to the Salpausselkä end morains, in: The Late Quaternary stratigraphy and environments of northern Eurasia and the adjacent Arctic seas - new contributions from QUEEN: selected papers from the an- 
nual QUEEN workshop held in Øystese, Norway, April 1999, and in Lund, Sweden, April 2000, edited by: Thiede, J., Bauch, H., Hjort, C., and Mangerud, J., Global Planet. Changes, 31, $387-$ 405, 2001

Scibek, J. and Allen, D. M.: Modeled Impacts of Predicted Climate Change on Recharge and Groundwater Levels, Water Resour. Res., 42, W11405, doi:10.1029/2005WR004742, 2006.

Scibek, J., Allen, D. M., Cannon, A., and Whitfield, P.: Groundwater-surface water interaction under scenarios of climate change using a high-resolution transient groundwater model, J. Hydrol., 333, 165-181, 2007.

Shand, P. and Edmunds, W. M.: The Baseline Inorganic Chemistry of European Groundwaters, in: Natural Groundwater Quality, edited by: Edmunds, W. M. and Shand, P., Blackwell Publishing Ltd., 22-58, 2008.

Shotyk, W., Krachler, M., Aeschbach-Hertig, W., Hillier, S., and Zheng, J.: Trace elements in recent groundwater of an artesian ?ow system and comparison with snow: enrichments, depletions, and chemical evolution of the water, J. Environ. Monitor., 12, 208-217, 2010.

Soveri, J., Mäkinen, R., and Peltonen, K.: Changes in Groundwater Levels and Quality in Finland 1975-1999. Tummavuoren kirjapaino Oy, Helsinki, Finland, 2001.
STM: Decree of the Ministry of Social Affairs and Health (STM) relating to the quality and monitoring of water intended for human consumption No. 461/ 2000, available at: http://www.finlex. fi/fi/laki/kaannokset/2000/en20000461.pdf (last access: 4 April 2014), 2001.

Taylor, R. G. and Howard, K. W. F.: Groundwater recharge in the Victoria Nile basin of east Africa: support for the soil moisture balance approach using stable isotope tracers and flow modeling, J. Hydrol., 180, 31-53, 1996.

Templ, M., Filzmoser, P., and Reimann, C.: Cluster analysis applied to regional geochemical data: Problems and possibilities, Appl. Geochem., 23, 2198-2213, 2008.

UNEP - Lääne, A., Kraav, E., and Titova, G.: Baltic Sea - GIWA Regional assessment 17, University of Kalmar, Kalmar, Sweden, 2005.

USGS: GW_Chart (Version 1.26), US Geological Survey, available at: http://water.usgs.gov/nrp/gwsoftware/GW_Chart/GW_Chart. html (last access: 25 October 2012), 2012.

Vuorenmaa, J., Järvinen, O., and Vänni, T.: Sadeveden pitoisuus- ja laskeuma-arvot Suomessa vuonna 1997 (Concentrations of rainwater and deposition values in Finland during 1997), Finnish Environment Institute (SYKE), 1999 (in Finnish).

Ward, J. H.: Hierarchical grouping to optimise an objective function, J. Am. Stat. Assoc., 58, 236-244, doi:10.2307/2282967, 1963. 